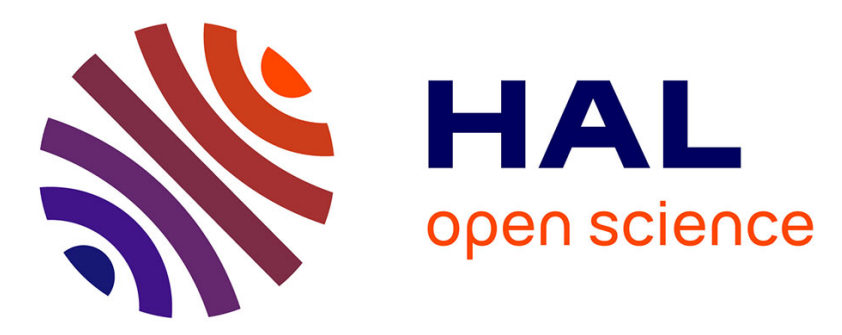

\title{
A novel TaqMan real-time polymerase chain reaction assay for verifying the authenticity of meat and commercial meat products from game birds
}

María Rojas, Isabel González, Miguel A. Pavón, Nicolette Pegels, Adriana Lago, Pablo Hernández, Teresa García, Rosario Martín

\section{To cite this version:}

María Rojas, Isabel González, Miguel A. Pavón, Nicolette Pegels, Adriana Lago, et al.. A novel TaqMan real-time polymerase chain reaction assay for verifying the authenticity of meat and commercial meat products from game birds. Food Additives and Contaminants, 2010, 27 (06), pp.749-763. 10.1080/19440040903503070 . hal-00593888

\section{HAL Id: hal-00593888 https://hal.science/hal-00593888}

Submitted on 18 May 2011

HAL is a multi-disciplinary open access archive for the deposit and dissemination of scientific research documents, whether they are published or not. The documents may come from teaching and research institutions in France or abroad, or from public or private research centers.
L'archive ouverte pluridisciplinaire $\mathbf{H A L}$, est destinée au dépôt et à la diffusion de documents scientifiques de niveau recherche, publiés ou non, émanant des établissements d'enseignement et de recherche français ou étrangers, des laboratoires publics ou privés. 


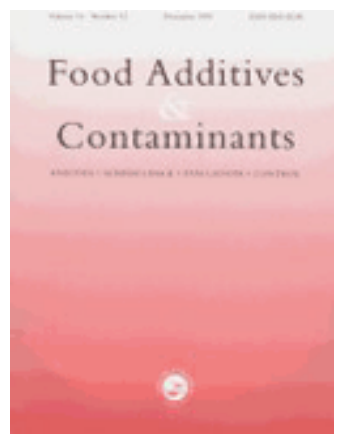

\section{A novel TaqMan real-time polymerase chain reaction assay for verifying the authenticity of meat and commercial meat products from game birds}

\begin{tabular}{|c|c|}
\hline Journal: & Food Additives and Contaminants \\
\hline Manuscript ID: & TFAC-2009-247.R2 \\
\hline Manuscript Type: & Original Research Paper \\
\hline $\begin{array}{r}\text { Date Submitted by the } \\
\text { Author: }\end{array}$ & 17-Nov-2009 \\
\hline Complete List of Authors: & $\begin{array}{l}\text { Rojas, María; Facultad de Veterinaria, UCM, Nutrición, Bromatología } \\
\text { y Tecnología de Ios Alimentos } \\
\text { González, Isabel; Facultad de Veterinaria, UCM, Nutrición, } \\
\text { Bromatología y Tecnología de los Alimentos } \\
\text { Pavón, Miguel A.; Facultad de Veterinaria, UCM, Nutrición, } \\
\text { Bromatología y Tecnología de los Alimentos } \\
\text { Pegels, Nicolette; Facultad de Veterinaria, UCM, Nutrición, } \\
\text { Bromatología y Tecnología de los Alimentos } \\
\text { Lago, Adriana; Facultad de Veterinaria, UCM, Nutrición, } \\
\text { Bromatología y Tecnología de los Alimentos } \\
\text { Hernández, Pablo; Facultad de Veterinaria, UCM, Nutrición, } \\
\text { Bromatología y Tecnología de los Alimentos } \\
\text { García, Teresa; Facultad de Veterinaria, UCM, Nutrición, } \\
\text { Bromatología y Tecnología de los Alimentos } \\
\text { Martín, Rosario; Facultad de Veterinaria, UCM, Nutrición, } \\
\text { Bromatología y Tecnología de los Alimentos }\end{array}$ \\
\hline Methods/Techniques: & Authenticity, Molecular biology - PCR, Traceability \\
\hline Additives/Contaminants: & Animal products \\
\hline Food Types: & Animal products - meat, Processed foods \\
\hline
\end{tabular}




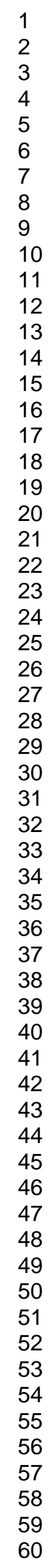

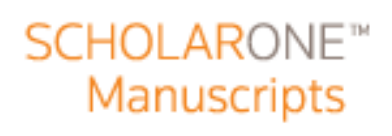

7

25

26

27

29

30

32

33

34

35

36

37

38

40

41

42

44

45

46

47

48

49

51

54

55

57

58

59

60

http://mc.manuscriptcentral.com/tfac Email: fac@tandf.co.uk 
1 A novel TaqMan real-time polymerase chain reaction assay for verifying the

2 authenticity of meat and commercial meat products from game birds.

3

4 María Rojas, Isabel González, Miguel Ángel Pavón, Nicolette Pegels, Adriana

5 Lago, Pablo E. Hernández, Teresa García, and Rosario Martín *

6

7 Departamento de Nutrición, Bromatología y Tecnología de los Alimentos, Facultad

8 de Veterinaria, Universidad Complutense, 28040 Madrid, Spain

$9 \quad$ *Corresponding author (mailing address):

10 Rosario Martín de Santos

11 Tel: 34-913943752

12 Fax: 34-913943743

13 E-mail: rmartins@vet.ucm.es

14

15

16

17

18

19

20

21

22 


\section{Abstract}

24 Species-specific real-time polymerase chain reaction (PCR) assays using TaqMan probes 25 have been developed for verifying the labeling of meat and commercial meat products from 26 game birds including quail, pheasant, partridge, guinea fowl, pigeon, Eurasian woodcock and 27 song thrush species. The method combines the use of species-specific primers and TaqMan 28 probes that amplify small fragments (amplicons $<150$ base pairs) of the mitochondrial $12 S$ 29 rRNA gene, and an endogenous control primer pair that amplifies a $141 \mathrm{bp}$ fragment of the 30 nuclear 18S rRNA gene from eukaryotic DNA. Analysis of experimental raw and heat-treated 31 binary mixtures as well as of commercial meat products from the target species, 32 demonstrated the suitability of the assay for the detection of the target DNAs.

Keywords: species identification; 12S rRNA; 18S rRNA; game birds; real-time PCR; 


\section{Introduction}

Traceability of food products has become a priority for governments of the developed countries, due to consumer demand for comprehensive and integrated food quality policies. In this context, food labeling legislation has become an 51 important issue because of the potential direct impact of labels on consumer 52 decision-making (Caporale et al. 2001; Verbeke and Ward, 2006). Meat products 53 sold for public consumption must be accurately labeled regarding species content 54 and thus, any ambiguity in the labeling practices of commercial suppliers is unacceptable. The fraudulent mislabeling of meat is a widespread problem, particularly with high added-value meat species commanding a premium price (Woolfe and Primrose, 2004). This has resulted in a need for tests which will reliably identify the species of meat present in a food sample and which also must be sensitive and robust enough to be applied to complex food matrices (Chisholm et al. 2005).

A particular type of product in which adulteration may take place is game bird meat. This type of meat can be found in gourmet foods that tend to be eaten on special occasions and because of their specialized nature, command high prices. As 64 consumer's tastes and choices broaden, the demand for less common game type meats is likely to grow, together with the need for reliable and rapid methods to ensure the accurate labeling of these products (Chisholm et al. 2008). Such methods must be developed to protect both consumers and producers from frauds, but also to 68 prevent over-exploitation and illegal trafficking of game meat products through the 69 food market (Fajardo et al. 2007). 
To accomplish meat authentication, a range of analytical approaches have been tackled, broadly based on detecting either protein or DNA molecules (Teletchea et al. 2005). In comparison with proteins, DNA-based methods have proved to be more reliable because of the stability of DNA under the conditions associated with the high temperature, pressures and chemical treatments used in the preparation of some meat products (Rodríguez et al. 2004). DNA-based methods have commonly been based around the use of conventional PCR with species-specific primers (Di Pinto et al. 2005; Che Man et al. 2007; Kesmen et al. 2007; Martín et al. 2007a; Rojas et al. 2009). However, this technique presents limitations such as the requirement of post-amplification handling of PCR products, thereby extending the risk of laboratory contamination and false-positive results, and the dependence on agarose gel electrophoresis for analysis of the products. More recently published reports have focused on the use of specific primers in real-time PCR (Dooley et al. 2004; Tanabe et al. 2007; Fajardo et al. 2008a). This technique has provided sensitive and safe solutions by monitoring PCR products continuously using fluorescent markers that eliminate the need for post-PCR processing steps, easing automation of the technique and large scale sample processing (Zhang et al. 2007).

In this paper, we describe the development of a real-time PCR approach for the detection of quail (Coturnix coturnix), pheasant (Phasianus colchicus), partridge (Alectoris spp), guinea fowl (Numida meleagris), pigeon (Columba spp), Eurasian woodcock (Scolopax rusticola), and song thrush (Turdus philomelos) DNAs in raw and heat-treated meat mixtures, and commercial meat products using TaqMan fluorogenic probes as detection platform. The assay targets species-specific sequences on the 12S rRNA gene and makes use of a eukaryotic system based on an 18S rRNA fragment as endogenous control. 


\section{Material and methods}

\section{Selection and preparation of meat samples}

Authentic muscle samples of quail (Coturnix coturnix), pheasant (Phasianus colchicus), red-legged partridge (Alectoris rufa), guinea fowl (Numida meleagris), Eurasian woodcock (Scolopax rusticola), woodpigeon (Columba palumbus), and song thrush (Turdus philomelos), were provided by Antonio de Miguel (Madrid, Spain). Red-legged partridge samples were also obtained from the Estación Biológica de Doñana (Sevilla, Spain) and from Hermanos Sainz (Madrid, Spain). Chukar partridge (Alectoris chukar) meat samples were provided by Hermanos Sainz (Madrid, Spain). Barbary partridge (Alectoris barbara) meat samples were obtained from the Department of Animal Production (Facultad de Veterinaria, Universidad Complutense de Madrid). Common pigeon (Columba livia) meat samples were provided by Industria del Pichón Bravío (Valladolid, Spain). Capercaillie (Tetrao urogallus) meat samples were obtained from the Department of Animal Pathology (Facultad de Veterinaria, Universidad Autónoma de Barcelona, Spain). Chicken (Gallus gallus), turkey (Meleagris gallopavo), Muscovy duck (Cairina moschata), and goose (Anser anser) meat samples were obtained from several local abattoirs and retail markers (Madrid, Spain). Muscle samples from cattle (Bos taurus), sheep (Ovis aries), goat (Capra hircus), swine (Sus scrofa domestica), red-deer (Cervus elaphus), fallow-deer (Dama dama), roe-deer (Capreolus capreolus), chamois (Rupicapra rupicapra), mouflon (Ovis ammon), and pyrenean ibex (Capra pyrenaica) were also obtained from several Spanish abattoirs and meat-cutting installations. All specimens were morphologically identified by professional veterinaries before obtaining the samples. Fresh muscle portions from the selected specimens were processed immediately or stored frozen at $-20^{\circ} \mathrm{C}$ until use. 
120 Binary mixtures of quail, pheasant, partridge, guinea fowl, pigeon, Eurasian

121 woodcock, or song thrush, in a chicken meat matrix were prepared using raw

122 muscles from the selected species. For each meat mixture, six different percentages

123 containing $50 \%, 25 \%, 10 \%, 5 \%, 1 \%$, and $0.1 \%(\mathrm{wt} / \mathrm{wt})$ of the target species were

124 prepared to a final weight of $100 \mathrm{~g}$. Forty $\mathrm{ml}$ of sterile phosphate-buffered saline

125 (PBS; $136 \mathrm{mM} \mathrm{NaCl}, 1.4 \mathrm{mM} \mathrm{KH}_{2} \mathrm{PO}_{4}, 8.09 \mathrm{mM} \mathrm{Na}_{2} \mathrm{H} \mathrm{PO}_{4} .12 \mathrm{H}_{2} \mathrm{O}$, and $2.6 \mathrm{mM} \mathrm{KCl}$,

$126 \mathrm{pH}$ 7.2) were added to the binary mixtures and they were homogenized with a

127 blender (Sunbeam Oster, Florida, USA). Fifty grams of each mixture were sterilized

128 at $121^{\circ} \mathrm{C}$ for 20 min to check the effect of thermal treatments on the technique's

129 ability to identify the target species. Raw and sterilized binary meat mixtures were

130 processed directly or stored at $-20^{\circ} \mathrm{C}$ until use.

131 Several commercial meat products from quail, pheasant, partridge, guinea

132 fowl, pigeon, Eurasian woodcock and song thrush species purchased from different

133 retail markets (Spain) were also included in the analysis.

\section{DNA extraction}

Total DNA was extracted from meat using a Wizard ${ }^{\circledR}$ DNA Clean-up System kit

136 (Promega Corp., Madison, WI) as described in a previous work (Rojas et al. 2008).

137 DNA concentration was measured with a NanoDrop ND-1000 spectrophotometer 138 (NanoDrop Technologies Inc., Montchanin, DE).

\section{Primers and oligonucleotide probes design}

140 Based upon detailed analysis and comparison of the alignment of $12 \mathrm{~S}$ rRNA 141 sequences from quail, pheasant, red-legged partridge, chukar partridge, barbary 142 partridge, guinea fowl, woodpigeon, Eurasian woodcock, song thrush, capercaillie, 143 chicken, turkey, Muscovy duck and goose (Rojas et al. 2009), seven species-specific 
144 primer pairs were designed: 12SCOT-FW/12SCOT-REV, 12SPHA-FW/12SPHA-

145 REV, 12SALEC-FW/12SALEC-REV, 12SNUM-FW/12SNUM-REV, 12SCOLU146 FW/12SCOLU-REV, 12SSCO-FW/12SSCO-REV, and 12STUR-FW/12STUR-REV.

147 They were expected to yield specific fragments of $129,113,141,130,133,138$, and $148110 \mathrm{bp}$ in the 12S rRNA gene of quail, pheasant, partridge, guinea fowl, pigeon,

149 Eurasian woodcock and song thrush, respectively. Quail, pheasant, partridge, and 150 guinea fowl primers were designed in a previous work (Rojas et al. 2009) whereas 151 pigeon, Eurasian woodcock, and song thrush primers were designed in this work.

152 Besides, a conserved $141 \mathrm{bp}$ fragment of the 18S rRNA gene flanked by 18SpEUDIR 153 and 18SpEUINV primers was used as endogenous control of the assay.

154 The EMMA program included in the EMBOSS software package version 2.0 155 and Primer Express 2.0 software (Perkin-Elmer/Applied Biosystems Division, Foster 156 City, CA) were used for sequence alignment and primer design.

157 Due to the high degree of sequence similarity between the species selected, 158 only limited regions could be used to design species-specific primers. The different 159 position of the species-specific primers designed made not possible the use of a 160 common probe for the seven species selected. Thus, taking into account the position 161 of the primer pairs designed, species-specific TaqMan probes were designed for the 162 detection of quail (QUAIL-TM), pheasant (PHEASANT-TM), Eurasian woodcock 163 (WOODCOCK-TM), and song thrush (THRUSH-TM) respectively, whereas a 164 common probe (BIRDS-TM) was designed for the detection of partridge, guinea fowl, 165 and pigeon species. Besides, another TaqMan probe (18SPROBE) based on 166 conserved 18S rRNA gene sequences available in the Genbank/EMBL database for 167 various avian and mammal species was used together with 18SpEUDIR and 168 18SpEUINV primers as endogenous control PCR system. 
TaqMan probes were designed and synthesized by TibMolBiol (Berlin,

170 Germany). The TaqMan probes were aimed to anneal within the gene fragment

171 generated by amplification of the corresponding target and were labeled on the 5'

172 end with the fluorescent reporter dye 6-carboxyfluorescein (FAM) and on the 3' end 173 with the blackberry (BBQ) fluorescent quencher.

174 In addition, species-specific primers developed in previous works (Martín et al. 175 2007b, 2007c, 2008) for chicken, turkey, duck, cattle, and swine were used in 176 conventional PCR assays for the analysis of complex meat products from the target 177 species in order to verify the composition stated in the labels.

178 The sequences and description of the primers and probes used in this work 179 are summarized in Table 1.

\section{PCR conditions}

Real-time PCR was run under generic cycling conditions. The optimum PCR

182 concentrations of primers yielding highest endpoint fluorescence and the lowest $\mathrm{C}_{p}$

183 were experimentally determined for each set of primers. Optimum concentrations

184 per reaction for each primer are shown in Table 1. The PCR reactions were carried 185 out using the LightCycler ${ }^{\circledR} \operatorname{TaqMan}^{\circledR}$ Master (Roche Diagnostics GmbH, 186 Mannheim, Germany), 2 pmol of each TaqMan probe (TibMolBiol), and 5 ng of 187 DNA. Amplification reactions were performed in a total reaction volume of $10 \mu \mathrm{L}$ in 188 a glass capillary tube and were run on the LightCycler ${ }^{\circledR} 2.0$ Instrument (Roche 189 Applied Science, Pensberg, Germany) with the following program: 10 min at $95 \stackrel{\circ}{ }$ 190 (denaturation and Taq polymerase activation), an amplification program of 35 191 cycles at $95^{\circ} \mathrm{C}$ for $10 \mathrm{~s}, 65^{\circ} \mathrm{C}$ (for quail, partridge, guinea fowl, and Eurasian 192 woodcock), $63^{\circ} \mathrm{C}$ (for pigeon, and song thrush), or $60^{\circ} \mathrm{C}$ (for pheasant) for $30 \mathrm{~s}$, 
193 and $72^{\circ} \mathrm{C}$ for $1 \mathrm{~s}$. Samples were then cooled to $40^{\circ} \mathrm{C}$ for $30 \mathrm{~s}$. The same program

194 was used to amplify each of the species-specific systems along with the

195 endogenous control PCR fragment. The crossing point value $\left(C_{p}\right)$, which refers to

196 the cycle number where the sample's fluorescence significantly increases above

197 the background level of fluorescence, was calculated automatically by the

198 LightCycler $^{\circledR}$ software as the first maximum of the second derivative of the curve.

199 Unless otherwise indicated, all real-time PCR reactions were carried out in 200 duplicate.

\section{Construction of standard curves and data analysis}

In order to check the ability of the real-time PCR method for quantitative

detection, standard curves were constructed using different percentages $(50,25,10$,

2045 , 1, and $0.1 \%$ ) of raw and sterilized binary meat mixtures from quail, pheasant, 205 partridge, guinea fowl, pigeon, Eurasian woodcock, and song thrush.

$\mathrm{C}_{\mathrm{p}}$ values obtained from each sample with the corresponding species-specific 207 system $\left(\mathrm{C}_{p} \mathrm{SP}\right)$ were normalized according to the following equation:

$C_{p} S P S=C_{p} E U^{*} C_{p} S P / C_{p} E U S$

where $\mathrm{C}_{p}$ SPS is the normalized $\mathrm{C}_{p}$ value of the sample analyzed with the 210 corresponding specific PCR system, $C_{p} E U$ is the $C_{p}$ average value of the standard 211 samples (binary mixtures) in the endogenous PCR system, and $C_{p} E U S$ is the $C_{p}$ 212 value of the sample analyzed with the endogenous PCR system.

213 In quantification analysis, a standard curve of standard samples plotted 214 against their crossing point is used to determine the concentration of unknown 215 samples. The amount of target DNA in an unknown sample can be measured by 216 interpolation of the normalized $C_{p}$ value obtained in the unknown sample in the 
217 corresponding standard curve of $C_{p}$ values generated from known DNA percentages 218 of the target species.

219 Besides, the correlation between the variables, crossing point $\left(C_{p}\right)$ and 220 concentration ([ ] ) is semilogarithmic:

$221 \quad C_{p}=b \log []+a$

222 Where $b$ is the slope and $a$ is the intercept.

223 Linearity test, sensitivity, accuracy and precision parameters of the species224 specific real-time PCR systems were evaluated according to previously described 225 methods (Camacho et al. 1993; ICH Harmonized Tripartite Guideline. 2005). To 226 carry out the validation of the real-time PCR technique developed in this work, three 227 separate DNA extractions of each mixture percentage were assayed in different 228 days, using two replicates of each sample. Precision of the assay was evaluated by 229 comparing the coefficient of variation (CV) values obtained in three different days 230 versus those obtained in the same day, to asses the influence of random events 231 (day of analysis, analyst, equipment, etc.) in the data obtained from the binary 232 mixtures.

\section{Results and discussion}

\section{Real-time PCR system set-up}

The primary objective of the PCR system setup was to establish an adequate 236 marker for game bird species identification. As target for real-time PCR, a fragment 237 of the mitochondrial 12S rRNA gene was selected. This mitochondrial gene was 238 chosen because it shows an appropriate degree of intra- and inter-species variability, 239 and because of the high number of copies found per cell. The presence of a high 240 copy number of mitochondrial DNA molecules in a cell significantly increases the 
241 sensitivity of the PCR assay when the tissue is subjected to extreme processing 242 conditions, such as sterilization (Girish et al. 2004).

243 To develop a robust method for detection of quail, pheasant, partridge, guinea

244 fowl, pigeon, Eurasian woodcock, and song thrush species in meat mixtures and 245 commercial meat products, seven species-specific primers and an eukaryotic primer 246 set (endogenous control) were combined in a real-time PCR method. The use of an 247 18S rRNA conserved region as an endogenous control has several purposes: a) it 248 provides a positive control on the total PCR-amplifiable eukaryotic DNA present in 249 the sample because factors affecting variation of target DNA amplification such as 250 PCR inhibition, degradation and quality of the DNA recovered from a sample can be 251 taken into account; b) it traces the presence of DNA that has not been amplified by 252 the species-specific detectors; c) by comparison of species-specific versus 253 endogenous control signal obtained from the samples, the inaccuracies caused by 254 the use of standards and unknowns can be reduced. 256 guinea fowl, pigeon, Eurasian woodcock, and song thrush primers amplified 257 fragments of $129,113,141,130,133,138,110$ bp in the $12 S$ rRNA gene, 258 respectively. These small amplicons are ideal for use with processed foods where 259 DNA degradation can mean that larger targets (>150 bp) are not always amplified 260 (Dooley et al. 2004). On the other hand, the endogenous control primer pair was 261 designed to amplify a DNA fragment of $141 \mathrm{bp}$ from all the eukaryotic organisms 262 tested with approximately the same efficiency. All PCR systems used species263 specific TaqMan probes, excepting those for partridge, guinea fowl, and pigeon 264 species in which, due to the similar position of the species-specific primers in the $12 S$ 265 rRNA sequence, a common probe was used. 
266

267

268

269

270

271

272

273

274

275

276

277

278

279

280

281

282

283

284

285

286

287

288

289

290

\section{Specificity}

Each species-specific PCR system was tested for its selectivity and cross reactivity by analysis of DNAs obtained from different game and domestic meat species. All species were analyzed in duplicate (two separate extractions and PCR reactions from each species).

The quail-specific system amplified a 129 bp fragment from quail ( $C_{p}$ value of $20.39 \pm 0.19)$, whereas no amplification was achieved with DNA from other game and domestic meat species. Similarly, pheasant, partridge, guinea fowl, pigeon, Eurasian woodcock, and song thrush-specific systems amplified fragments of $113,141,130$, 133, 138, and $110 \mathrm{bp}$, respectively, in samples from each corresponding target species, showing no cross amplification with DNAs from the rest of the meat species analyzed. The $C_{p}$ values obtained from raw meat samples were $17.1 \pm 0.04$ in pheasant, 19.14 \pm 0.06 in red-legged partridge, 19.23 \pm 0.08 in chukar partridge, $19.19 \pm 0.10$ in barbary partridge, $16.15 \pm 0.04$ in guinea fowl, $16.32 \pm 0.07$ in common pigeon, 16.40 \pm 0.04 in woodpigeon, 18.22 \pm 0.06 in Eurasian woodcock, and $16.03 \pm 0.08$ in song thrush, whereas in non-template controls no amplification signal was detected after 35 cycles (Table 2). The endogenous control system amplified a $141 \mathrm{bp}$ fragment from all the eukaryotic species analyzed. With this system, all tested species showed $C_{p}$ values between $16.69 \pm 0.03$ and $20.30 \pm 0.06$.

\section{Efficiency and detection limit}

The efficiency and detection limit of the real-time PCR assay developed were evaluated from the standard curve made with the experimental binary mixtures containing $50 \%, 25 \%, 10 \%, 5 \%, 1 \%$, and $0.1 \%$ of either quail, pheasant, partridge, guinea fowl, pigeon, Eurasian woodcock, or song thrush meat in a chicken meat matrix. Five ng of DNA from each binary mixture percentage was analyzed with the 
291 corresponding species-specific system and with the endogenous control system.

292 Normalization was carried out on fluorescence results obtained for each mixture with 293 the seven species-specific systems and with the endogenous control, and these data 294 were used as the calibration curve for further statistical studies. Results of the 295 efficiency of the PCR approach for raw experimental binary mixtures are shown in 296 Figure 1 and Figure 2. The slope of log input amount vs. $\Delta C_{p}$ has a value of -3.04 for 297 the quail-specific system (1a), -3.26 for pheasant-specific system (1b), -3.09 for 298 partridge-specific system (1c), -3.11 for guinea fowl-specific system (1d), -3.00 for 299 pigeon-specific system (1e), -3.98 for Eurasian woodcock-specific system (1f), and 3003.16 for song thrush-specific system $(1 \mathrm{~g})$, near to the slope's value of -3.32 301 corresponding to a 100\% PCR efficiency. Similarly, Figure 3 and Figure 4 show the 302 results obtained after analyzing the sterilized experimental mixtures.

The theoretical detection limit for each species-specific PCR system was also 304 calculated from the standard curves obtained with the experimental binary mixtures 305 shown in Figures 1-4. The detection limit for each species-specific system was 306 estimated from the corresponding curve as the DNA amount yielding a $C_{p}$ value of 307 35. This value was $8.4 \times 10^{-5} \mathrm{ng}$ in quail, $1.62 \times 10^{-5} \mathrm{ng}$ in pheasant, $2.08 \times 10^{-5} \mathrm{ng}$ in 308 partridge, $4.2 \times 10^{-6} \mathrm{ng}$ in guinea fowl, $1.36 \times 10^{-5} \mathrm{ng}$ in pigeon, $6.7 \times 10^{-5} \mathrm{ng}$ in Eurasian 309 woodcock, and $3.34 \times 10^{-6} \mathrm{ng}$ in song thrush. On the other hand, in sterilized binary 310 mixtures, the detection limits for DNA from quail, pheasant, partridge, guinea fowl, 311 pigeon, Eurasian woodcock, and song thrush specific PCR systems were $1.3 \times 10^{-3}$ $312 \mathrm{ng}, 6.45 \times 10^{-5} \mathrm{ng}, 4.08 \times 10^{-4} \mathrm{ng}, 3.68 \times 10^{-5} \mathrm{ng}, 1.21 \times 10^{-5} \mathrm{ng}, 5.38 \times 10^{-4} \mathrm{ng}$, and $3.2 \times 10^{-5}$

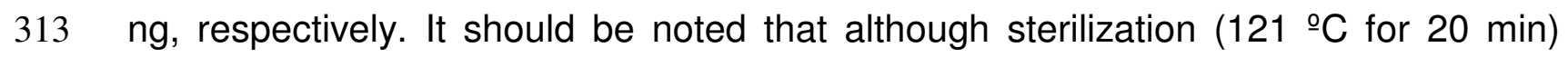
314 reduces the amount of detectable DNA, positive signals were also observed in 315 thermally treated samples containing small percentages of the target species DNA. It 
316 is widely reported that the intensity of the heating and pressure of food processing

317 treatments such as sterilization clearly affects DNA fragmentation and can lead to 318 false-negative results (Hird et al. 2006). In the present work, the length of the 319 amplified DNA fragments minimized sensitivity to degraded DNA templates.

320 It can be deduced from the results obtained that the real-time PCR method 321 developed allows quantification of minute amounts of DNA as long as the reference 322 sample used has received the same treatment than the samples analyzed. So, 323 because of the variations found in the amount and quality of amplifiable DNA in the

324 real-time PCR assay developed, different calibration curves should be used in 325 accordance with the target species, the tissue matrix and the heat treatment applied 326 in order to achieve reliable quantification of target meat content.

\section{Sensitivity and linearity}

Normalized $\mathrm{C}_{\mathrm{p}}$ values obtained from the raw and heat-treated meat mixtures of 329 quail, pheasant, partridge, guinea fowl, pigeon, Eurasian woodcock, and song thrush

330 in chicken, versus the logarithm of the DNA concentrations, were used to test the 331 sensitivity of the real-time PCR method. Figures 1-4 show the discriminating 332 capacity, which is the least difference in logarithm of target DNA concentration in the 333 mixture that the analytical method can discriminate with a significant level. Linearity 334 of the quail, pheasant, partridge, guinea fowl, pigeon, Eurasian woodcock, and song 335 thrush real-time PCR response was also analyzed for each experimental raw and 336 heat treated binary mixture. In each case, the following parameters were evaluated:

337 (a) Cochran's test, which determined whether the variances of the responses 338 obtained for each concentration of quail, pheasant, partridge, guinea fowl, pigeon, 339 Eurasian woodcock, or song thrush DNA in the mixtures (raw and heat-treated) were 
340 homogeneous, (b) regression analysis, and (c) variance analysis with Lack-of-Fit.

341 The results are also summarized in Figures-4.

\section{$342 \quad$ Accuracy and precision}

The accuracy of the assay was determined from three meat percentages $344(25 \%, 10 \%$, and $1 \%)$ of each raw and heat-treated binary mixture. Accuracy is 345 reported as percentage recovery by the assay of known added amounts of analyte. 346 Using the Snedecor F-test, it was verified that the concentration of DNA present in a 347 sample did not affect the variation of the results. The values of the Student's t-test 348 obtained demonstrated that the method was accurate, since no significant 349 differences between $100 \%$ and the mean recovery values were detected.

The influence of the day of analysis on the precision of the assay was also 351 tested by comparing the coefficients of variation (CV) of three separate DNA 352 extractions performed on the $1 \%$ raw and sterilized binary mixtures, analyzed in 353 duplicate three times on the same day, versus the values obtained for the same 354 samples on three different days. Results showed significant differences with higher 355 CV values when the assay was done on different days with respect to the same day. 356 This could be ascribed to the fact that different master mix vials were used in the 357 assays performed on different days and it could be also attributed to minimal 358 volumetric variations caused by pipetting errors in any of the steps of the real-time 359 PCR experiment (DNA aliquot preparation, mix of reagents, dispensation of the 360 master mix into the PCR capillaries, etc.). Thus, for the quantification of quail, 361 pheasant, partridge, guinea fowl, pigeon, Eurasian woodcock, and song thrush 362 DNAs, a standard curve should be determined on each day of analysis. 
364 The method was also tested with regard to its suitability for detection of game 365 bird DNA in commercial meat products. For that purpose DNA samples extracted 366 from quail, pheasant, partridge, guinea fowl, pigeon, Eurasian woodcock, and song 367 thrush meat products were analyzed. As can be seen in Tables 3 and 4, the specific 368 and endogenous $C_{p}$ values obtained from the DNA samples extracted from these 369 commercial products were very variable, including those obtained in different pâté 370 samples with similar specified content of the target species (Table 4). This can be 371 attributed to a variation in factors such as meat quality, tissue type, matrix 372 composition, and levels of processing. It should be noted that, in most cases, the 373 results obtained from the analysis of meat products were in agreement with the 374 declaration of quail, pheasant, partridge, guinea fowl, pigeon, Eurasian woodcock, or 375 song thrush content on the label. However, seven partridge pâtés and one pheasant 376 pâté, which were supposed to contain partridge and pheasant respectively, did not 377 produce positive results with the corresponding species-specific real-time PCR 378 systems. Nevertheless, successful results were obtained with the endogenous 379 control system, suggesting a possible fraud in the labeling of these pâte samples 380 (Table 4). In addition, commercial meat samples containing more than one species in 381 their composition were also tested for the presence of other animal species stated in 382 the label such as chicken, turkey, cattle, swine and duck. For this purpose, 383 conventional PCR assays using species-specific primers for the mentioned species 384 were carried out. In all the samples tested, the results obtained were in accordance 385 with the species composition stated in the labels including the pâte samples in which 386 partridge and pheasant were not detected (Table 4). In order to test the usefulness of the method for the quantification of the target 388 species in commercial meat products containing more than one species in their 
389 composition, a quantitative measurement was performed substituting the normalized

$390 \quad \mathrm{C}_{\mathrm{p}}$ values obtained for these products in the standard equations derived from the 391 analysis of the experimental sterilized binary mixtures. As can be seen in Table 4 the

392 results obtained indicated a complete disagreement between the amounts detected 393 and the declared content of each target species. Although, as previously described, 394 this is a technique with quantitative potential, the use of the standard equations 395 developed in this work does not turn out to be suitable for the quantification of 396 commercial meat products because of two main reasons: the composition of the 397 commercial meat products that due to the presence of different ingredients could 398 influence in the real-time reaction, and the fact that it was not possible to know if the 399 heat-treatment applied to each product was similar to the sterilization treatment used 400 in the present work (121 ${ }^{\circ} \mathrm{C}, 20 \mathrm{~min}$ ). In consequence, the $\mathrm{C}_{\mathrm{p}}$ values measured on 401 commercial meat products can only be used for a quantitative estimate of the target 402 species content if samples identical in composition and processing treatment to the 403 analyzed products are available for the preparation of appropriate calibration 404 standards. Taking into account the great variety of ingredients used in the 405 preparation of commercial meat products (meat, liver, fat, oil, milk, butter, vegetables, 406 etc.) as well as the diversity of heat treatments applied by the meat industry, the 407 preparation of calibration standards for each type of product is not feasible. 408 Therefore, the use of the present real-time PCR technique for the analysis of 409 commercial meat products is limited to qualitative detection of the target species. 410 Nevertheless it should be noted that quail, pheasant, partridge, guinea fowl, pigeon, 411 Eurasian woodcock, and song thrush qualitative detection in commercial meat 412 products was not hindered by the heat and pressure processing of autoclaving, oven 
413 cooking, pickling, or by the presence of other meats, indicating the suitability of the 414 assays for the testing of complex commercial food products (Chisholm et al. 2008).

415 In conclusion, TaqMan real-time polymerase chain reaction is a powerful 416 technology that is simple and relatively fast, with good sensitivity and specificity. The 417 potential of the described procedure to detect small amounts of quail, pheasant, 418 partridge, guinea fowl, pigeon, Eurasian woodcock, and song thrush DNA in raw and 419 heat-treated meats may make it a useful tool for inspection programs to enforce 420 labeling regulations of game bird meat products.

\section{ACKNOWLEDGEMENTS}

422 This study was supported by Grant No. AGL 2007-60077 from the Ministerio 423 de Educación y Ciencia of Spain and the Programa de Vigilancia Sanitaria S424 0505/AGR/000265 from the Comunidad de Madrid (Spain). María Rojas and Miguel 425 Ángel Pavón are recipients of a fellowship from the Ministerio de Ciencia e 426 Innovación (Spain). Nicolette Pegels is recipient of a fellowship from the Comunidad 427 de Madrid (Spain).

428 We are indebted to Dr. Santiago Lavin González (Facultad de Veterinaria, 429 Universidad Autónoma de Barcelona), Dr. Juan José Negro Balmaseda (Estación 430 Biológica de Doñana, Sevilla), and Dra. Susana Dunner (Facultad de Veterinaria, 431 Universidad Complutense de Madrid) for kindly supplying capercaillie, red-legged 432 partridge, and barbary partridge samples. 


\section{REFERENCES}

438 1. Camacho MA, Torres Al, Gil-Alegre ME, Obregón MM, Ruz V. 1993. Validation 439 protocol of analytical methods for finished pharmaceutical products. STP Pharm $440 \quad$ Pract. 3:197-202.

441 2. Caporale V, Giovannini A, Di Francesco C, Calistri, P. 2001. Importance of the 442 traceability of animals and animal products in epidemiology. Rev Sci Tech Off Int $443 \quad$ Epiz. 20:372-378.

444 3. Che Man YB, Aida AA, Raha AR, Son R. 2007. Identification of pork derivatives in 445 food products by species-specific polymerase chain reaction (PCR) for halal 446 verification. Food Control. 18:885-889.

447 4. Chisholm J, Conyers C, Booth C, Lawley W, Hird H. 2005. The detection of horse 448 and donkey using real-time PCR. Meat Sci. 70:727-732.

449 5. Chisholm J, Sánchez A, Brown J, Hird H. 2008. The development of species450 specific real-time PCR assays for the detection of pheasant and quail in food. $451 \quad$ Food Anal Methods. 1:190-194.

452 6. Di Pinto A, Forte VT, Conversano MC, Tantillo GM. 2005. Duplex polymerase 453 chain reaction for detection of pork meat in horse meat fresh sausages from 454 Italian retail sources. Food Control. 16:391-394.

455 7. Dooley JJ, Paine KE, Garrett SD, Brown HM. 2004. Detection of meat species 456 using TaqMan real-time PCR assays. Meat Sci. 68:431-438.

457 8. Fajardo V, González I, Martín I, López-Calleja I, Rojas M, Hernández PE, García 458 T, Martín R. 2007. PCR identification of meats from chamois (Rupicapra 459 rupicapra), pyrenean ibex (Capra pyrenaica), and mouflon (Ovis ammon) 
460 targeting specific sequences from the mitochondrial D-loop region. Meat Sci. $461 \quad 76: 644-652$.

462 9. Fajardo V, González I, Martín I, Rojas M, Hernández PE, García T, Martín R. 463 2008a. Real-time PCR for detection and quantification of red deer (Cervus 464 elaphus), fallow deer (Dama dama), and roe deer (Capreolus capreolus) in meat 465 mixtures. Meat Sci. 79:289-298.

466 10. Girish PS, Anjaneyulu ASR, Viswas KN, Anand M, Rajkumar N, Shivakumar BM, 467 Sharma B. 2004. Sequence analysis of mitochondrial 12S rRNA gene can identify 468 meat species. Meat Sci. 66:551-556.

469 11. Hird H, Chisholm J, Sánchez A, Hernández M, Goodier R, Schneede K. 2006. 470 Effect of heat and pressure processing on DNA fragmentation and implications for 471 the detection of meat using a real-time polymerase chain reaction. Food Addit 472 Contam. 23:645-650.

473 12. ICH Harmonised Tripartite Guideline. 2005. Validation of analytical procedures: 474 text and methodology Q2 (R1).

475 13. Kesmen Z, Sahin F, Yetim H. 2007. PCR assay for the identification of animal 476 species in cooked sausages. Meat Sci. 77:649-653.

477 14. Martín I, García T, Fajardo V, López-Calleja I, Rojas M, Hernández PE, González 478 I, Martín R. 2007a. Mitochondrial markers for the detection of four duck species 479 and the specific identification of Muscovy duck in meat mixtures using the 480 polymerase chain reaction. Meat Sci. 76:721-729.

481 15. Martín I, García T, Fajardo V, López-Calleja I, Hernández PE, González I, Martín 482 R. 2007b. Species-specific PCR for the identification of ruminant species in 483 feedstuffs. Meat Sci. 75:120-127. 
484 16. Martín I, García T, Fajardo V, López-Calleja I, Rojas M, Pavón MA, Hernández 485 PE, González I, Martín R. 2007c. Detection of chicken, turkey, duck, and goose 486 tissues in feedstuffs, using species-specific polymerase chain reaction. J Anim 487 Sci. $85: 452-458$.

17. Martín I, García T, Fajardo V, Rojas M, Pegels N, Hernández PE, González I, 489 Martín R. 2008. SYBR-Green real-time PCR approach for the detection and 490 quantification of pig DNA in feedstuffs. Meat Sci. 82:252-259.

491 18. Rodríguez MA, García T, González I, Asensio L, Hernández PE, Martín R. 2004. 492 Quantitation of mule duck in goose foie gras using TaqMan real-time polymerase $493 \quad$ chain reaction. J Agric Food Chem. 52:1478-1483.

494 19. Rojas M, González I, Fajardo V, Martín I, Hernández PE, García T, Martín R. 495 2008. Polymerase chain reaction-restriction fragment length polymorphism 496 authentication of raw meats from game birds. J. AOAC Int. 91:1416-1422.

497 20. Rojas M, González I, Fajardo V, Martín I, Hernández PE, García T, Martín R. 498 2009. Authentication of meats from quail (Coturnix coturnix), pheasant (Phasianus 499 colchicus), partridge (Alectoris spp.), and guinea fowl (Numida meleagris) using 500 polymerase chain reaction targeting specific sequences from the mitocondrial $12 \mathrm{~S}$ $501 \quad$ rRNA gene. Food Control. 20:896-902.

502 21. Tanabe S, Hase M, Yano T, Sato M, Fujimura T, Akiyama H. 2007. A real-time 503 quantitative PCR detection method for pork, chicken, beef, mutton, and horseflesh $504 \quad$ in foods. Biosci Biotechnol Biochem. 71:3131-3135.

505 22. Teletchea F, Maudet C, Hänni C. 2005. Food and forensic molecular 506 identification: Update and challenges. Trends Biotechnol. 23:359-366. 
507 23. Verbeke W, Ward RW. 2006. Consumer interest in information cues denoting 508 quality, traceability and origin: an application of ordered probit models to beef $509 \quad$ labels. Food Qual Prefer. 17:453-467.

510 24. Woolfe M, Primrose S. 2004. Food forensics: using DNA technology to combat 511 misdescription and fraud. Trends Biotechnol. 22:222-226.

512 25.Zhang C, Fowler MR, Scott NW, Lawson G, Slater A. 2007. A TaqMan real-time 513 PCR system for the identification and quantification of bovine DNA in meats, milks 514 and cheeses. Food Control. 18:1149-1158. 


\section{FIGURE CAPTIONS}

516 FIGURE 1. Normalized $C_{p}$ values obtained from raw meat mixtures of quail (1a), 517 pheasant (1b), partridge (1c), and guinea fowl (1d) in chicken, plotted versus the

518 logarithm of the DNA concentrations. Linearity test, regression line and sensitivity 519 parameters are calculated for each species-specific PCR system. Three different 520 DNA extractions performed on different percentages of quail, pheasant, partridge, or 521 guinea fowl $(50,25,10,5,1$ and $0.1 \%)$ species in the raw meat mixtures were used 522 as standards.

523 FIGURE 2. Normalized $C_{p}$ values obtained from raw meat mixtures of pigeon (2a), 524 Eurasian woodcock (2b), and song thrush (2c) in chicken, plotted versus the 525 logarithm of the DNA concentrations. Linearity test, regression line and sensitivity 526 parameters are calculated for each species-specific PCR system. Three different 527 DNA extractions performed on different percentages of pigeon, Eurasian woodcock, 528 or song thrush $(50,25,10,5,1$ and $0.1 \%)$ species in the raw meat mixtures were 529 used as standards.

530 FIGURE 3. Normalized $C_{p}$ values obtained from sterilized meat mixtures of quail 531 (3a), pheasant (3b), partridge (3c), and guinea fowl (3d) in chicken, plotted versus 532 the logarithm of the DNA concentrations. Linearity test, regression line and 533 sensitivity parameters are calculated for each species-specific PCR system. Three 534 different DNA extractions performed on different percentages of quail, pheasant, 535 partridge, or guinea fowl $(50,25,10,5,1$ and $0.1 \%)$ species in the sterilized meat 536 mixtures were used as standards.

537 FIGURE 4. Normalized $C_{p}$ values obtained from sterilized meat mixtures of pigeon 538 (4a), Eurasian woodcock (4b), and song thrush (4c) in chicken, plotted versus the 
539 logarithm of the DNA concentrations. Linearity test, regression line and sensitivity 540 parameters are calculated for each species-specific PCR system. Three different 541 DNA extractions performed on different percentages of pigeon, Eurasian woodcock, 542 or song thrush $(50,25,10,5,1$ and $0.1 \%)$ species in the sterilized meat mixtures 543 were used as standards.

544 545 


\section{FIGURE 1}

$1 a$

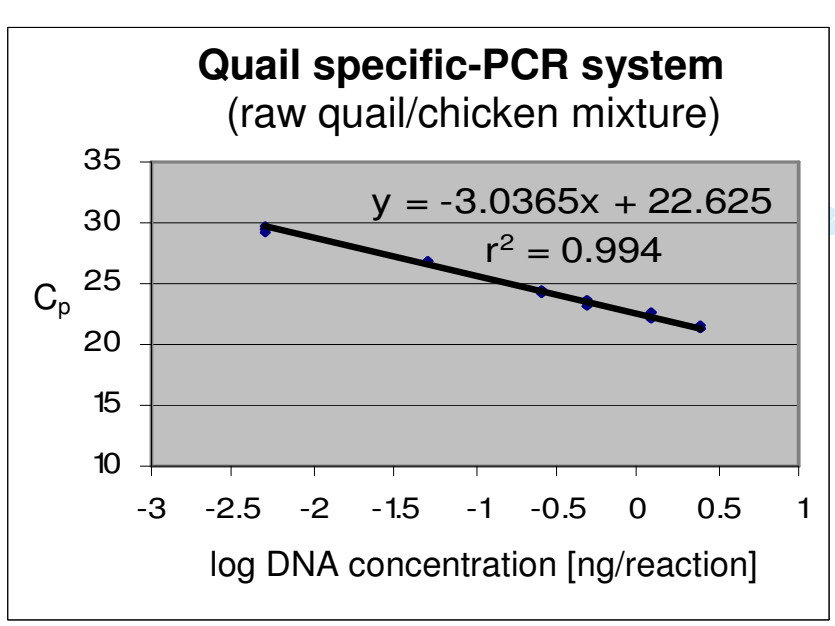

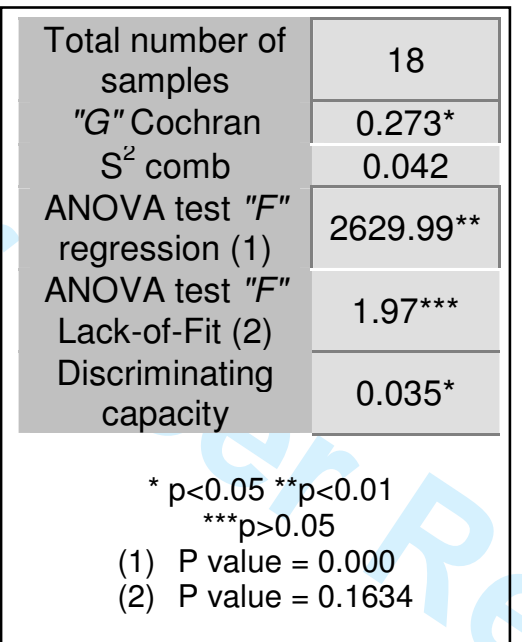

1c

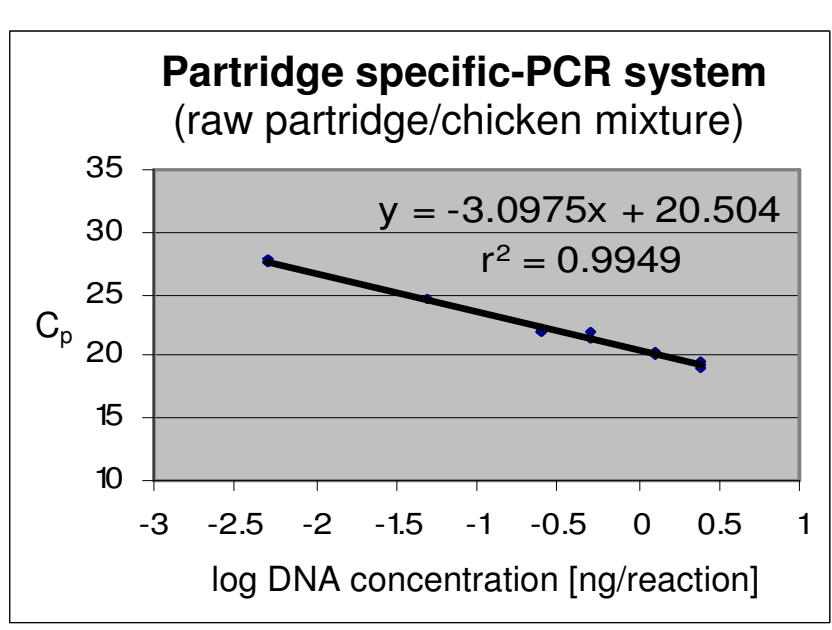

\begin{tabular}{|c|c|}
\hline \multirow{4}{*}{$\begin{array}{l}\text { Total number of } \\
\text { samples } \\
\text { "G" Cochran } \\
\mathrm{S}^{2} \text { comb } \\
\text { ANOVA test "F" } \\
\text { regression (1) }\end{array}$} & 18 \\
\hline & $0.366^{*}$ \\
\hline & 0.036 \\
\hline & 3106.31 ** \\
\hline \multirow{2}{*}{$\begin{array}{l}\text { ANOVA test "F" } \\
\text { Lack-of-Fit (2) } \\
\text { Discriminating } \\
\text { capacity }\end{array}$} & $2.08^{\star \star \star}$ \\
\hline & $0.029 *$ \\
\hline \multicolumn{2}{|c|}{$\begin{array}{l}{ }^{*} p<0.05^{* *} p<0.01 \\
\text { (1) } P \text { value }=0.000 \\
\text { (2) } P \text { value }=0.1467\end{array}$} \\
\hline
\end{tabular}

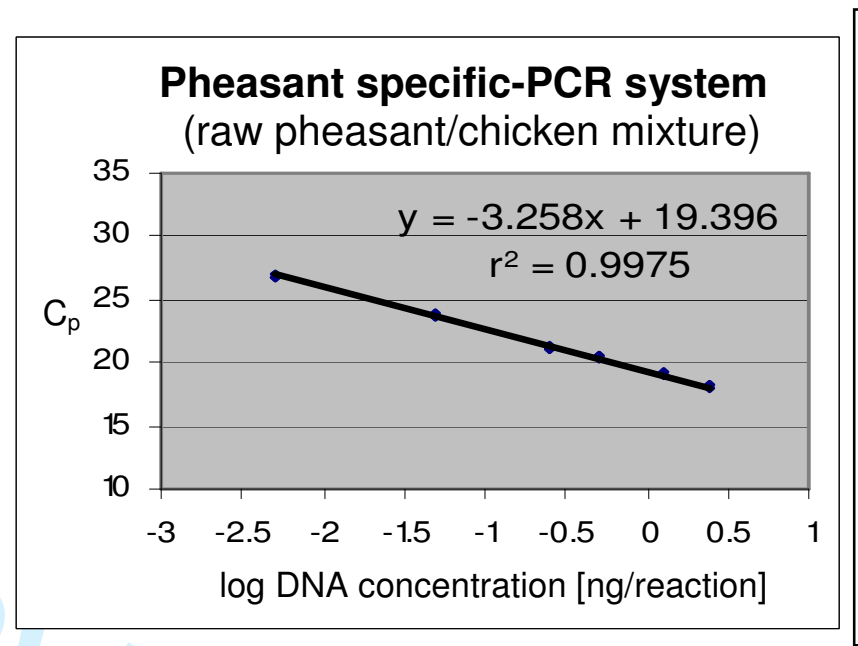

\begin{tabular}{|c|c|}
\hline \multirow{4}{*}{$\begin{array}{l}\text { Total number of } \\
\text { samples } \\
\text { "G" Cochran } \\
\mathrm{S}^{2} \text { comb } \\
\text { ANOVA test "F" } \\
\text { regression (1) }\end{array}$} & 18 \\
\hline & $0.380^{*}$ \\
\hline & 0.022 \\
\hline & $6382.12^{* *}$ \\
\hline $\begin{array}{l}\text { ANOVA test " } F " \\
\text { Lack-of-Fit (2) }\end{array}$ & $1.34^{\star \star \star}$ \\
\hline $\begin{array}{l}\text { Discriminating } \\
\text { capacity }\end{array}$ & $0.006^{*}$ \\
\hline $\begin{array}{l}{ }^{*} p<0.05 * \\
{ }^{* * *} p>0 . \\
\text { (1) } P \text { value }= \\
\text { (2) P value }=\end{array}$ & $\begin{array}{l}<<0.01 \\
5 \\
0.000 \\
0.3125\end{array}$ \\
\hline
\end{tabular}

\section{1d}

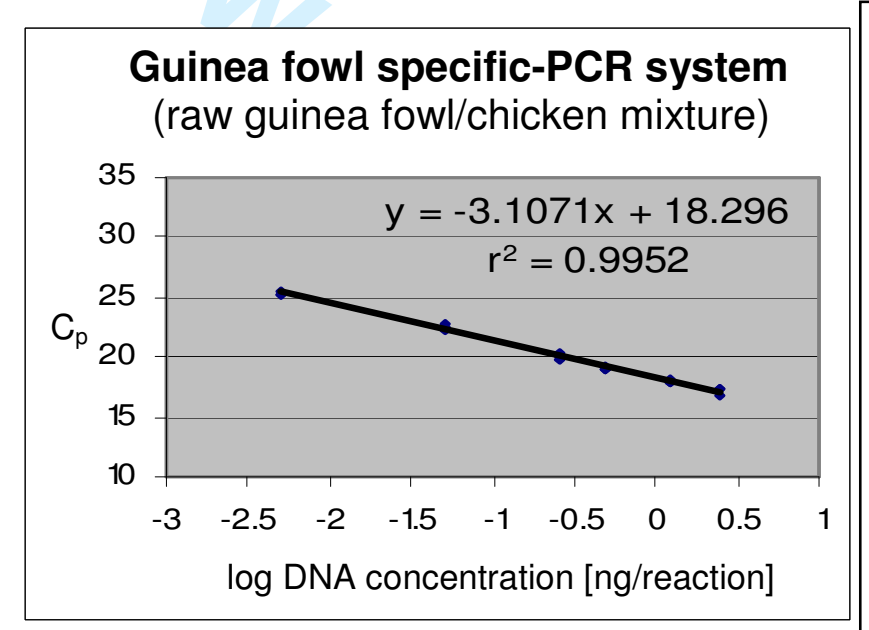




\section{FIGURE 2}

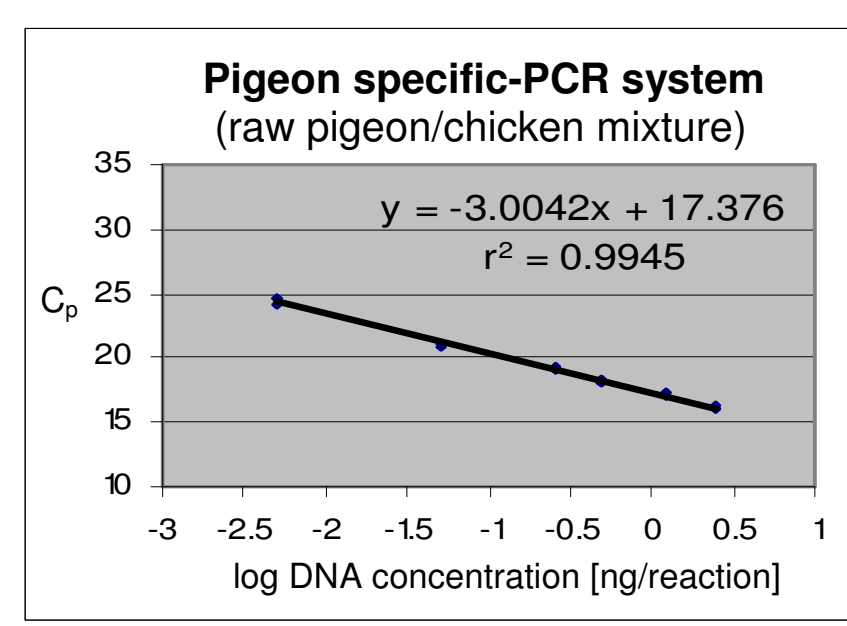

\begin{tabular}{|c|c|}
\hline Total number of & 18 \\
\hline $\begin{array}{l}\text { "G" Cochran } \\
S^{2} \text { comb }\end{array}$ & $\begin{array}{l}0.311^{*} \\
0.029\end{array}$ \\
\hline $\begin{array}{l}\text { ANOVA test "F" } \\
\text { regression (1) }\end{array}$ & $3352.02^{* *}$ \\
\hline $\begin{array}{l}\text { ANOVA test "F" } \\
\text { Lack-of-Fit (2) }\end{array}$ & $2.86^{\star * *}$ \\
\hline $\begin{array}{l}\text { Discriminating } \\
\text { capacity }\end{array}$ & $0.024^{*}$ \\
\hline \multicolumn{2}{|c|}{$\begin{array}{l}{ }^{*} p<0.055^{* *} p<0.01 \\
{ }^{* \star *} p>0.05 \\
\text { (1) } P \text { value }=0.000 \\
\text { (2) } P \text { value }=0.0858\end{array}$} \\
\hline
\end{tabular}

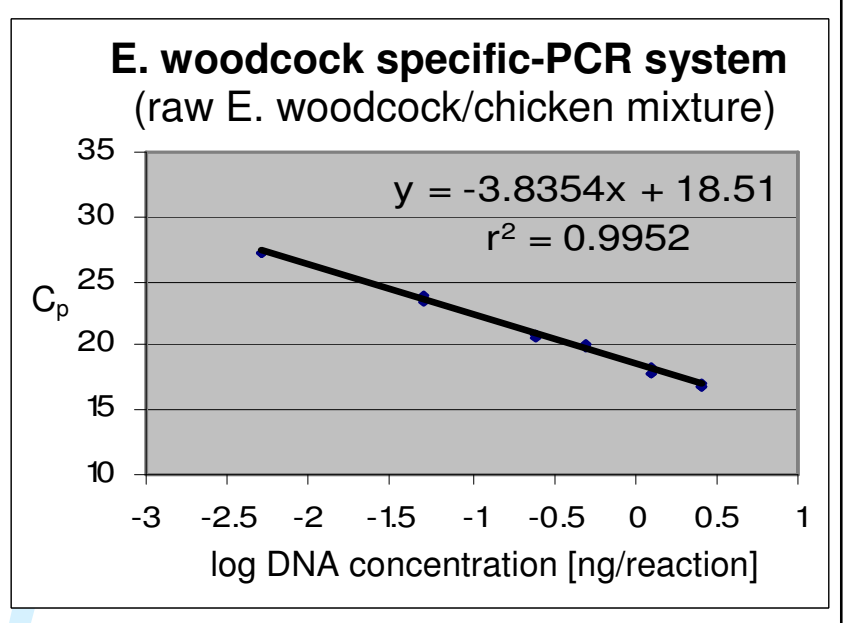

\begin{tabular}{|c|c|}
\hline \multirow{4}{*}{$\begin{array}{l}\text { Total number of } \\
\text { samples } \\
\text { "G" Cochran } \\
S^{2} \text { comb } \\
\text { ANOVA test "F" } \\
\text { rearession (1) }\end{array}$} & 18 \\
\hline & $0.304^{*}$ \\
\hline & 0.053 \\
\hline & $3054.71^{* *}$ \\
\hline \multirow{2}{*}{$\begin{array}{l}\text { ANOVA test " } F " \\
\text { Lack-of-Fit }(2) \\
\text { Discriminating } \\
\text { capacity }\end{array}$} & $2.76^{* * *}$ \\
\hline & $0.034^{*}$ \\
\hline \multicolumn{2}{|c|}{$\begin{array}{c}{ }^{*} p<0.05{ }^{* *} p<0.01 \\
{ }^{* *} p>0.05 \\
\text { (1) } P \text { value }=0.000 \\
\text { (2) } P \text { value }=0.0777\end{array}$} \\
\hline
\end{tabular}

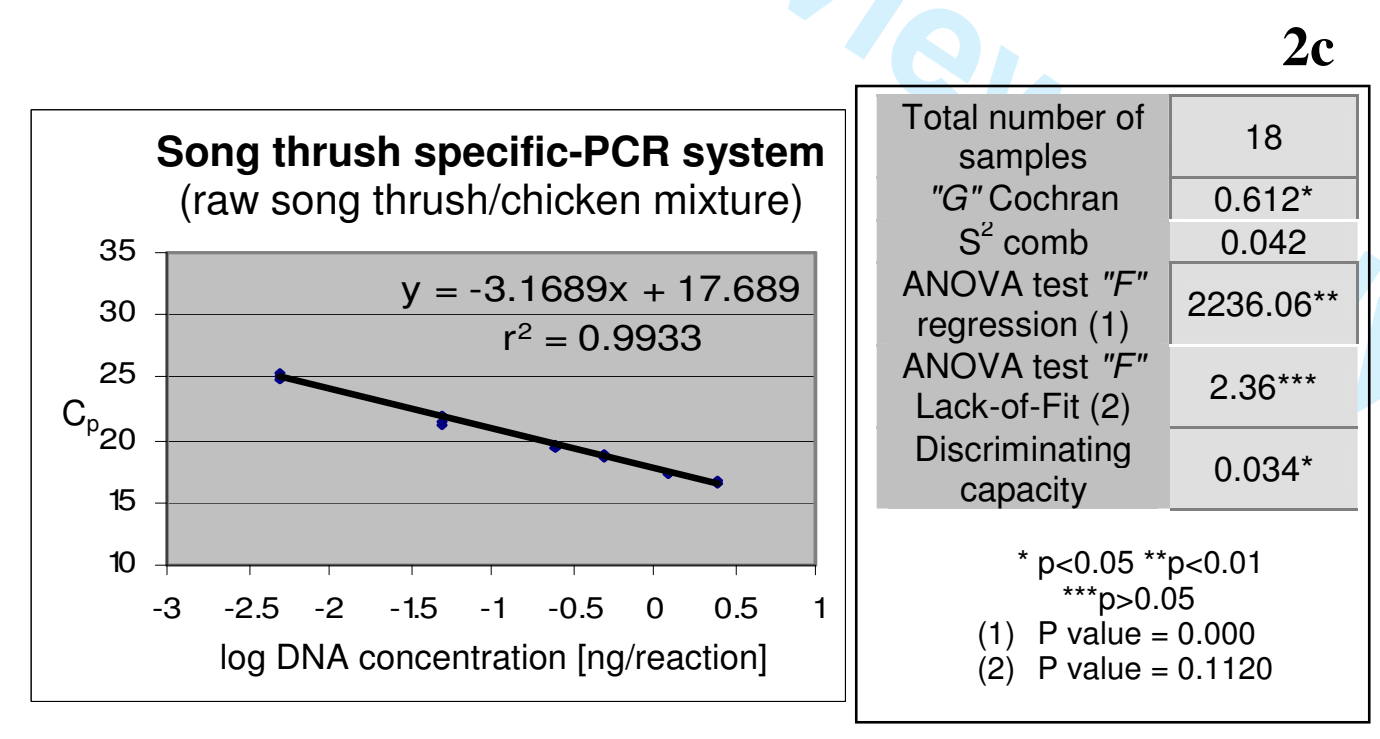




\section{FIGURE 3}
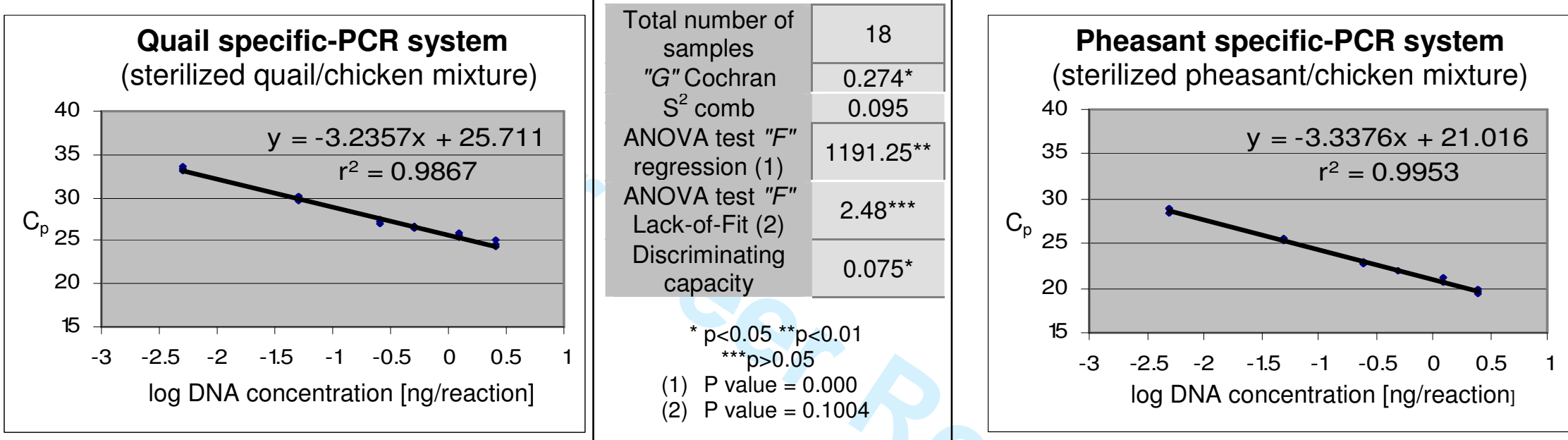

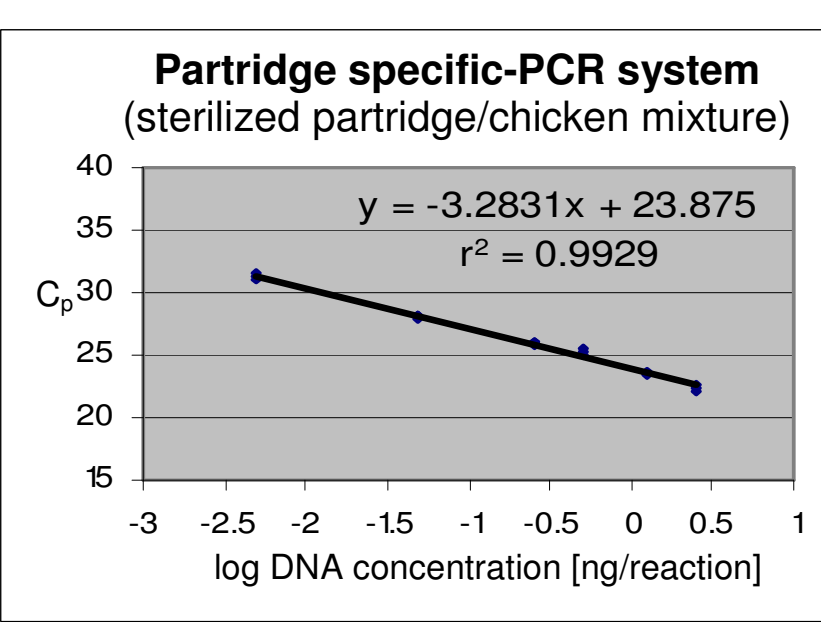

\begin{tabular}{|c|c|}
\hline Total number of & 18 \\
\hline "G" Cochran & $0.274^{*}$ \\
\hline $\mathrm{S}^{2} \mathrm{comb}$ & 0.095 \\
\hline $\begin{array}{l}\text { ANOVA test "F" } \\
\text { regression (1) }\end{array}$ & $1191.25^{\star *}$ \\
\hline $\begin{array}{l}\text { ANOVA test " } F " \\
\text { Lack-of-Fit (2) }\end{array}$ & $2.48^{* * *}$ \\
\hline $\begin{array}{l}\text { Discriminating } \\
\text { capacity }\end{array}$ & $0.075^{*}$ \\
\hline $\begin{array}{l}{ }^{*} p<0.05{ }^{* *} \\
\text { (1) } p>0.0 \\
\text { (1) } P \text { value }= \\
\text { (2) } P \text { value }=\end{array}$ & $\begin{array}{l}0.01 \\
000 \\
1004\end{array}$ \\
\hline
\end{tabular}

$3 \mathbf{c}$

3a

\begin{tabular}{|c|c|}
\hline \multirow{4}{*}{$\begin{array}{l}\text { Total number of } \\
\text { samples } \\
\text { "G" Cochran } \\
S^{2} \text { comb } \\
\text { ANOVA test "F" } \\
\text { regression (1) }\end{array}$} & 18 \\
\hline & $0.338^{*}$ \\
\hline & 0.047 \\
\hline & $2244.63^{* *}$ \\
\hline \multirow{2}{*}{$\begin{array}{l}\text { ANOVA test "F" } \\
\text { Lack-of-Fit (2) } \\
\text { Discriminating } \\
\text { capacity }\end{array}$} & $2.99^{\star \star \star}$ \\
\hline & $0.037^{*}$ \\
\hline \multicolumn{2}{|c|}{$\begin{array}{l}{ }^{*} p<0.05^{* *} p<0.01 \\
\text { (1) } P \text { value }=0.000 \\
\text { (2) } P \text { value }=0.0629\end{array}$} \\
\hline
\end{tabular}

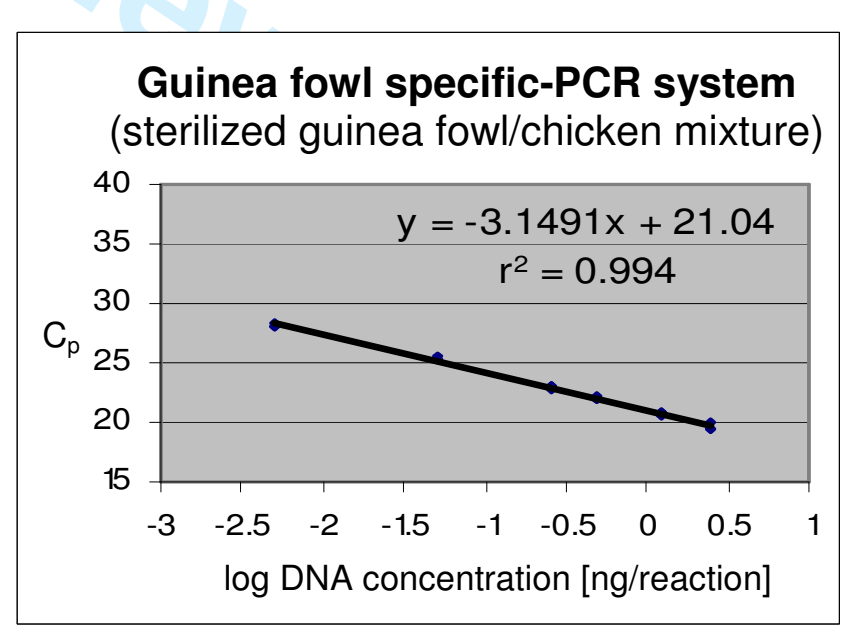

\begin{tabular}{|c|c|}
\hline \multirow{2}{*}{$\begin{array}{l}\text { Total number of } \\
\text { samples } \\
\text { "G" Cochran }\end{array}$} & 18 \\
\hline & $0.334^{*}$ \\
\hline \multirow{2}{*}{$\begin{array}{l}\mathrm{S}^{2} \text { comb } \\
\text { ANOVA test "F" } \\
\text { regression (1) }\end{array}$} & 0.037 \\
\hline & $3373.74^{\star *}$ \\
\hline \multirow{2}{*}{$\begin{array}{l}\text { ANOVA test "F" } \\
\text { Lack-of-Fit (2) } \\
\text { Discriminating } \\
\text { capacity }\end{array}$} & $2.29^{* * *}$ \\
\hline & $0.028^{*}$ \\
\hline \multicolumn{2}{|c|}{$\begin{array}{l}{ }^{*} p<0.05^{* *} p<0.01 \\
{ }^{* * *} p>0.05 \\
\text { (1) } P \text { value }=0.000 \\
\text { (2) } P \text { value }=0.1634\end{array}$} \\
\hline
\end{tabular}

3d

$3 \mathbf{b}$

\begin{tabular}{|c|c|}
\hline \multirow{4}{*}{$\begin{array}{l}\text { Total number of } \\
\text { samples } \\
\text { "G" Cochran } \\
S^{2} \text { comb } \\
\text { ANOVA test "F" } \\
\text { regression (1) }\end{array}$} & 18 \\
\hline & $0.298^{*}$ \\
\hline & 0.040 \\
\hline & $2648.42^{\star *}$ \\
\hline $\begin{array}{l}\text { ANOVA test "F" } \\
\text { Lack-of-Fit (2) }\end{array}$ & $2.48^{\star \star \star}$ \\
\hline $\begin{array}{l}\text { Discriminating } \\
\text { capacity }\end{array}$ & $0.033^{*}$ \\
\hline $\begin{array}{l}{ }^{*} p<0.05^{* *} p \\
{ }^{* * *} p>0.05 \\
\text { (1) } P \text { value }= \\
\text { (2) } P \text { value }=0\end{array}$ & $\begin{array}{l}000 \\
0998\end{array}$ \\
\hline
\end{tabular}




\section{FIGURE 4}

$4 a$

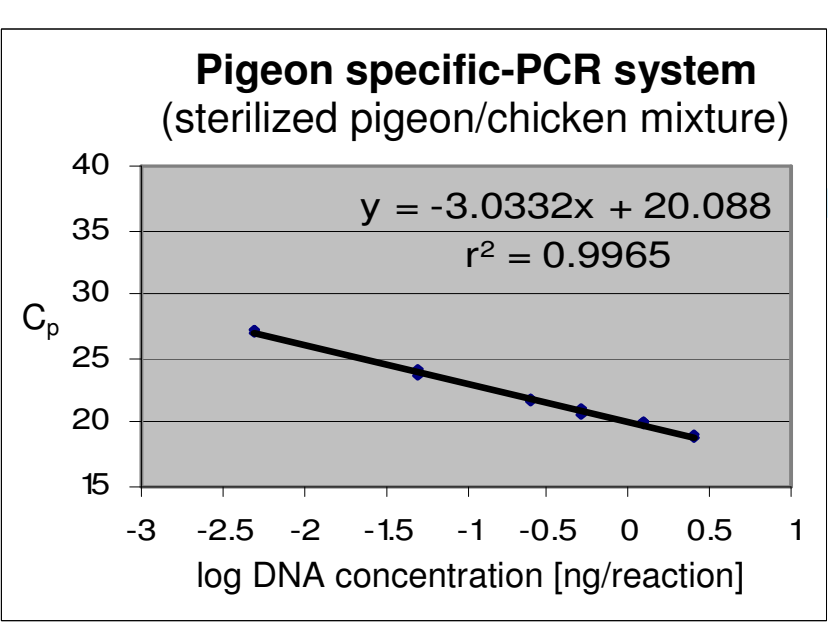

\begin{tabular}{|c|c|}
\hline \multirow{6}{*}{$\begin{array}{l}\text { Total number of } \\
\text { samples } \\
\text { "G" Cochran } \\
\mathrm{S}^{2} \text { comb } \\
\text { ANOVA test "F" } \\
\text { regression (1) } \\
\text { ANOVA test " } F \text { " } \\
\text { Lack-of-Fit (2) } \\
\text { Discriminating } \\
\text { capacity }\end{array}$} & 18 \\
\hline & $0.246^{*}$ \\
\hline & 0.024 \\
\hline & $4535.56^{* *}$ \\
\hline & $2.08^{\star * \star}$ \\
\hline & $0.020^{*}$ \\
\hline $\begin{array}{l}{ }^{*} p<0.05{ }^{* *} p \\
{ }^{* * *} p>0.0 \\
\text { (1) } P \text { value }= \\
\text { (2) } P \text { value }=\end{array}$ & $\begin{array}{l}=0.01 \\
.000 \\
.1459\end{array}$ \\
\hline
\end{tabular}

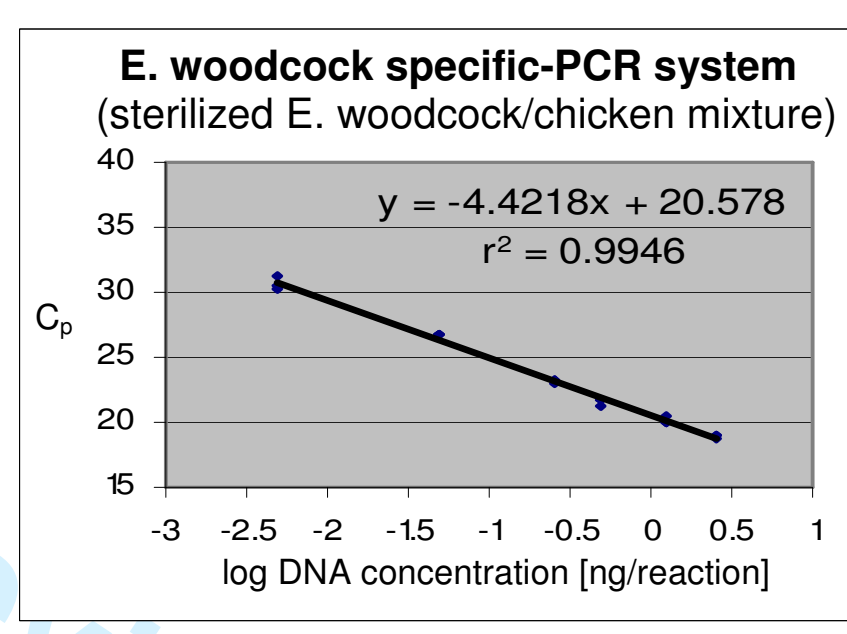

\section{4c}

\begin{tabular}{|c|c|}
\hline Total number of & 18 \\
\hline "G" Cochran & $0.401^{*}$ \\
\hline $\mathrm{S}^{2} \mathrm{comb}$ & 0.064 \\
\hline $\begin{array}{l}\text { ANOVA test "F" } \\
\text { regression (1) }\end{array}$ & $2192.53^{* *}$ \\
\hline $\begin{array}{l}\text { ANOVA test " } F " \\
\text { Lack-of-Fit (2) }\end{array}$ & $1.26^{\star * \star}$ \\
\hline $\begin{array}{l}\text { Discriminating } \\
\text { capacity }\end{array}$ & $0.052^{*}$ \\
\hline $\begin{array}{l}{ }^{*} p<0.05{ }^{* *} p \\
{ }^{* * *} p>0.0 \\
\text { (1) } P \text { value }= \\
\text { (2) } P \text { value }=\end{array}$ & $\begin{array}{l}0.01 \\
000 \\
3373\end{array}$ \\
\hline
\end{tabular}

$4 b$

\begin{tabular}{|c|c|}
\hline \multirow{2}{*}{$\begin{array}{l}\text { Total number of } \\
\text { samples } \\
\text { "G" Cochran }\end{array}$} & 18 \\
\hline & $0.535^{*}$ \\
\hline $\mathrm{S}^{2} \mathrm{comb}$ & 0.069 \\
\hline $\begin{array}{l}\text { ANOVA test "F" } \\
\text { regression (1) }\end{array}$ & $2952.16^{* *}$ \\
\hline $\begin{array}{l}\text { ANOVA test "F" } \\
\text { Lack-of-Fit (2) }\end{array}$ & $2.67^{* * *}$ \\
\hline $\begin{array}{l}\text { Discriminating } \\
\text { capacity }\end{array}$ & $0.040^{*}$ \\
\hline $\begin{array}{l}{ }^{*} p<0.05{ }^{* *} p \\
{ }^{* * *} p>0.05 \\
\text { (1) } P \text { value }=0 \\
\text { (2) } P \text { value }=\end{array}$ & $\begin{array}{l}0.01 \\
000 \\
0843\end{array}$ \\
\hline
\end{tabular}

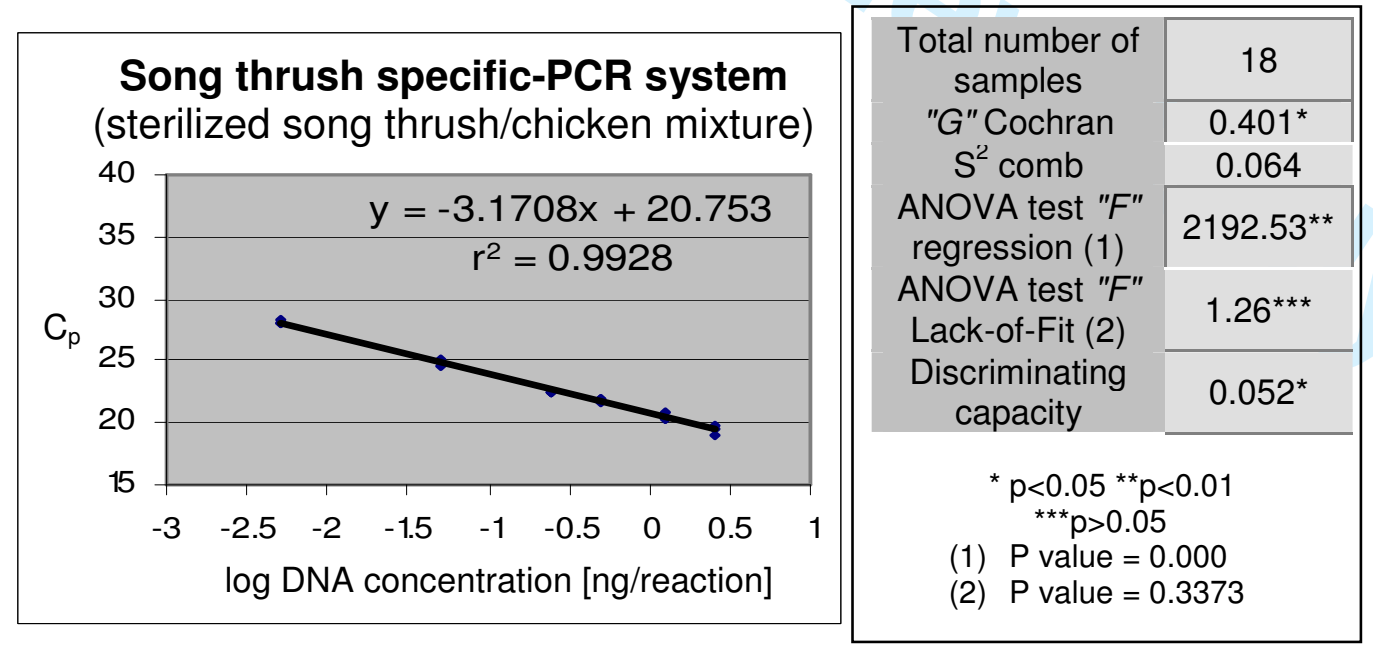




\section{TABLE 1}

DNA sequences of the primers and probes used in this study

\begin{tabular}{|c|c|c|c|c|c|}
\hline Primers and probes & Length (bp) & Sequence ( $5^{\prime}$ to $\left.3^{\prime}\right)$ & Description & Optimal concentration (nM) & \\
\hline 18SpEU-DIR & 29 & GGTAGTGACGAAAAATAACAATACAGGAC & Endogenous control forward primer & 300 & \\
\hline 18SpEU-INV & 25 & ATACGCTATTGGAGCTGGAATTACC & Endogenous control reverse primer & 900 & \\
\hline 12SCOT-FW & 27 & GATTTAGCAGTAAAATGGGATCACTTT & Quail forward primer & 300 & \\
\hline 12SCOT-REV & 22 & TCGTCTTTGGCTTAATGGTTGG & Quail reverse primer & 900 & \\
\hline 12SPHA-FW & 23 & AGTGGTCATATGTTATCCTCACC & Pheasant forward primer & 900 & \\
\hline 12SPHA-REV & 21 & GGGGTAAAATTAGTCGTGGAG & Pheasant reverse primer & 900 & \\
\hline 12SALEC-FW & 26 & CGACCTAAAAACCATCTTAGTTCCCA & Partridge forward primer & 300 & \\
\hline 12SNUM-FW & 24 & АССТСAAAACAATCTTAGCCACCA & Guinea fowl forward primer & 300 & \\
\hline 12SNUM-REV & 25 & TTCTCAGGCGGATACTTAGGTATTG & Guinea fowl reverse primer & 900 & \\
\hline 12SCOLU-FW & 26 & GCCCTAAATACGACCCTAAACTCATA & Pigeon forward primer & 900 & Formatted: English U.K. \\
\hline 12SCOLU-REV & 23 & CAGGCGGATGCTTTGGTTATATA & Pigeon reverse primer & 900 & \\
\hline $12 \mathrm{SSCO}_{-} \mathrm{FW}$ & 27 & CAGCTCACCTCCAATGAGAGCTATATA & Eurasian woodcock forward primer & 300 & Deleted: $L$ \\
\hline 12SSCO-REV & 21 & ATGCCCCCTTCCGTATGGTTA & Eurasian woodcock reverse primer & 300 & Deleted: L \\
\hline 12STUR-FW & 24 & GAGTGGTCGCATGTTATCCAAGTA & Song thrush forward primer & 300 & \\
\hline 12STUR-REV & 29 & AATCGTTGTTCTAAGATCTTCTTTGAAGA & Song thrush reverse primer & 900 & \\
\hline QUAI-TM & 24 & FAM-CTTCAAAAGCTACTAATACCGATA-TMR & Quail probe & 200 & \\
\hline PHEASANT-TM & 30 & FAM-CCTAAGATCGAAGTACAACTAAGCTGTCAT-TMR & Pheasant probe & 200 & \\
\hline BIRDS-TM & 25 & FAM-ACGAAAGCCAGGRCACAAACTGGGA-TMR & Partridge, G. fowl and Pigeon probe & 200 & \\
\hline WOODCOCK-TM & 29 & FAM-CACAACCCACTAACAAGACAGGTCGAGGT-BBQ & Eurasian woodcock probe & 200 & \\
\hline THRUSH-TM & 29 & FAM-TGAGCTGTCATAAGCCCAAGATGCYCATA-BBQ & Song thrush probe & 200 & \\
\hline
\end{tabular}




\section{TABLE 2}

Specificity of quail, pheasant, partridge, guinea fowl, pigeon, Eurasian woodcock, and song thrush real-time PCR systems ( $\mathrm{C}_{\mathrm{p}}$ values obtained from 5 ng DNA)

\begin{tabular}{|c|c|c|c|c|c|c|c|}
\hline Species & $\begin{array}{c}\text { Quail specific PCR } \\
\text { system }\end{array}$ & $\begin{array}{l}\text { Pheasant specific } \\
\text { PCR system }\end{array}$ & $\begin{array}{l}\text { Partridge specific } \\
\text { PCR system }\end{array}$ & $\begin{array}{c}\text { Guinea fowl specific } \\
\text { PCR system }\end{array}$ & $\begin{array}{l}\text { Pigeon specific } \\
\text { PCR system }\end{array}$ & $\begin{array}{l}\text { E.woodcock specific } \\
\text { PCR system }\end{array}$ & $\begin{array}{l}\text { S.thrush specific } \\
\text { PCR system }\end{array}$ \\
\hline Quail (Coturnix coturnix) & $20.39 \pm 0.19$ & 35 & 35 & 35 & 35 & 35 & 35 \\
\hline Pheasant (Phasianus colchicus) & 35 & $17.01 \pm 0.04$ & 35 & 35 & 35 & 35 & 35 \\
\hline Red-legged partridge (Alectoris rufa) & 35 & 35 & $19.14 \pm 0.06$ & 35 & 35 & 35 & 35 \\
\hline Chukar partridge (Alectoris chukar) & 35 & 35 & $19.23 \pm 0.08$ & 35 & 35 & 35 & 35 \\
\hline Barbary partridge (Alectoris barbara) & 35 & 35 & $19.19 \pm 0.10$ & 35 & 35 & 35 & 35 \\
\hline Guinea fowl (Numida meleagris) & 35 & 35 & 35 & $16.15 \pm 0.04$ & 35 & 35 & 35 \\
\hline Common pigeon (Columba livia) & 35 & 35 & 35 & 35 & $16.32 \pm 0.07$ & 35 & 35 \\
\hline Woodpigeon (Columba palumbus) & 35 & 35 & 35 & 35 & $16.40 \pm 0.04$ & 35 & 35 \\
\hline Eurasian woodcock (Scolopax rusticola) & 35 & 35 & 35 & 35 & 35 & $18.22 \pm 0.06$ & 35 \\
\hline Song thrush (Turdus philomelas) & 35 & 35 & 35 & 35 & 35 & 35 & $16.03 \pm 0.08$ \\
\hline Capercaillie (Tetrao urogallus) & 35 & 35 & 35 & 35 & 35 & 35 & 35 \\
\hline Chicken (Gallus gallus) & 35 & 35 & 35 & 35 & 35 & 35 & 35 \\
\hline Turkey (Meleagris gallopavo) & 35 & 35 & 35 & 35 & 35 & 35 & 35 \\
\hline Muscovy duck (Cairina moschata) & 35 & 35 & 35 & 35 & 35 & 35 & 35 \\
\hline Goose (Anser anser) & 35 & 35 & 35 & 35 & 35 & 35 & 35 \\
\hline Cattle (Bos taurus) & 35 & 35 & 35 & 35 & 35 & 35 & 35 \\
\hline Sheep (Ovis aries) & 35 & 35 & 35 & 35 & 35 & 35 & 35 \\
\hline Goat (Capra hircus) & 35 & 35 & 35 & 35 & 35 & 35 & 35 \\
\hline Swine (Sus scrofa dom.) & 35 & 35 & 35 & 35 & 35 & 35 & 35 \\
\hline Fallow deer (Dama dama) & 35 & 35 & 35 & 35 & 35 & 35 & 35 \\
\hline Roe deer (Capreolus capreolus) & 35 & 35 & 35 & 35 & 35 & 35 & 35 \\
\hline Red deer (Cervus elaphus) & 35 & 35 & 35 & 35 & 35 & 35 & 35 \\
\hline Chamois (Rupicapra rupicapra) & 35 & 35 & 35 & 35 & 35 & 35 & 35 \\
\hline Mouflon (Ovis ammon) & 35 & 35 & 35 & 35 & 35 & 35 & 35 \\
\hline Pyrenean ibex (Capra pyrenaica) & 35 & 35 & 35 & 35 & 35 & 35 & 35 \\
\hline
\end{tabular}

Average $C_{p}$ value $\pm S D$ shown from duplicate reaction 


\section{TABLE 3}

$\mathrm{C}_{p}$ values obtained for PCR products amplified with species-specific primers from DNA extracted of raw and heat-treated commercial meat products containing only one species in their composition. ( $C_{p}$ values produced using $5 \mathrm{ng}$ DNA).

\begin{tabular}{|c|c|c|c|c|c|c|c|c|}
\hline Type of product & $\begin{array}{c}\text { Quail } \\
\text { specific } \\
\text { PCR system }\end{array}$ & $\begin{array}{l}\text { Pheasant } \\
\text { specific } \\
\text { PCR system }\end{array}$ & $\begin{array}{c}\text { Partridge } \\
\text { specific } \\
\text { PCR system }\end{array}$ & $\begin{array}{l}\text { Guinea fowl } \\
\text { specific } \\
\text { PCR system }\end{array}$ & $\begin{array}{c}\text { Pigeon } \\
\text { specific } \\
\text { PCR system }\end{array}$ & $\begin{array}{l}\text { E. woodcock } \\
\text { specific } \\
\text { PCR system }\end{array}$ & $\begin{array}{l}\text { Song thrush } \\
\text { specific } \\
\text { PCR system }\end{array}$ & $\begin{array}{c}\text { Endogenous } \\
\text { control PCR } \\
\text { system }\end{array}$ \\
\hline Quail pickled thighs A & $23.81 \pm 0.13$ & 35 & 35 & 35 & 35 & 35 & 35 & $23.14 \pm 0.13$ \\
\hline Quail pickled thighs B & $23.14 \pm 0.08$ & 35 & 35 & 35 & 35 & 35 & 35 & $21.56 \pm 0.08$ \\
\hline Quail pickled meat & $24.43 \pm 0.09$ & 35 & 35 & 35 & 35 & 35 & 35 & $20.52 \pm 0.13$ \\
\hline Quail boned pickled meat & $20.94 \pm 0.18$ & 35 & 35 & 35 & 35 & 35 & 35 & $21.48 \pm 0.18$ \\
\hline Quail braised meat & $20.80 \pm 0.21$ & 35 & 35 & 35 & 35 & 35 & 35 & $20.27 \pm 0.21$ \\
\hline Pheasant braised meat $A$ & 35 & $23.52 \pm 0.08$ & 35 & 35 & 35 & 35 & 35 & $22.38 \pm 0.14$ \\
\hline Pheasant braised meat B & 35 & $21.86 \pm 0.11$ & 35 & 35 & 35 & 35 & 35 & $22.07 \pm 0.21$ \\
\hline Pheasant ragout & 35 & $24.45 \pm 0.23$ & 35 & 35 & 35 & 35 & 35 & $23.19 \pm 0.13$ \\
\hline Partridge pickled thighs $\mathrm{A}$ & 35 & 35 & $24.66 \pm 0.27$ & 35 & 35 & 35 & 35 & $22.48 \pm 0.26$ \\
\hline Partridge pickled meat $A$ & 35 & 35 & $20.61 \pm 0.21$ & 35 & 35 & 35 & 35 & $23.50 \pm 0.22$ \\
\hline Partridge pickled meat $\mathrm{B}$ & 35 & 35 & $25.89 \pm 0.14$ & 35 & 35 & 35 & 35 & $24.04 \pm 0.17$ \\
\hline Partridge pickled meat $\mathrm{C}$ & 35 & 35 & $28.54 \pm 0.07$ & 35 & 35 & 35 & 35 & $25.02 \pm 0.13$ \\
\hline Partridge pickled meat $D$ & 35 & 35 & $24.58 \pm 0.21$ & 35 & 35 & 35 & 35 & $24.28 \pm 0.18$ \\
\hline Partridge pickled meat $\mathrm{E}$ & 35 & 35 & $27.85 \pm 0.11$ & 35 & 35 & 35 & 35 & $25.30 \pm 0.21$ \\
\hline Partridge pickled meat $F$ & 35 & 35 & $25.22 \pm 0.16$ & 35 & 35 & 35 & 35 & $23.25 \pm 0.22$ \\
\hline Partridge boned pickled meat $A$ & 35 & 35 & $28.61 \pm 0.06$ & 35 & 35 & 35 & 35 & $25.34 \pm 0.17$ \\
\hline Partridge boned pickled meat B & 35 & 35 & $27.36 \pm 0.21$ & 35 & 35 & 35 & 35 & $24.35 \pm 0.11$ \\
\hline Partridge stewed meat & 35 & 35 & $19.67 \pm 0.11$ & 35 & 35 & 35 & 35 & $18.02 \pm 0.23$ \\
\hline Partridge braised meat $A$ & 35 & 35 & $24.22 \pm 0.13$ & 35 & 35 & 35 & 35 & $22.35 \pm 0.17$ \\
\hline Partridge braised meat B & 35 & 35 & $25.72 \pm 0.16$ & 35 & 35 & 35 & 35 & $24.74 \pm 0.17$ \\
\hline G. fowl braised meat $A$ & 35 & 35 & 35 & $19.09 \pm 0.17$ & 35 & 35 & 35 & $19.48 \pm 0.19$ \\
\hline G. fowl braised meat B & 35 & 35 & 35 & $19.97 \pm 0.24$ & 35 & 35 & 35 & $20.14 \pm 0.24$ \\
\hline G. fowl stewed meat & 35 & 35 & 35 & $21.48 \pm 0.11$ & 35 & 35 & 35 & $22.85 \pm 0.17$ \\
\hline Pigeon pickled thighs & 35 & 35 & 35 & 35 & $26.13 \pm 0.32$ & 35 & 35 & $24.76 \pm 0.18$ \\
\hline Pigeon pickled meat $A$ & 35 & 35 & 35 & 35 & $25.80 \pm 0.15$ & 35 & 35 & $22.29 \pm 0.12$ \\
\hline Pigeon pickled meat B & 35 & 35 & 35 & 35 & $24.87 \pm 0.05$ & 35 & 35 & $24.14 \pm 0.37$ \\
\hline Pigeon braised meat & 35 & 35 & 35 & 35 & $26.43 \pm 0.22$ & 35 & 35 & $20.76 \pm 0.23$ \\
\hline E. woodcock refrigerated meat $A$ & 35 & 35 & 35 & 35 & 35 & $18.25 \pm 0.32$ & 35 & $21.85 \pm 0.14$ \\
\hline E. woodcock refrigerated meat B & 35 & 35 & 35 & 35 & 35 & $18.06 \pm 0.12$ & 35 & $21.94 \pm 0.05$ \\
\hline E. woodcock frozen meat & 35 & 35 & 35 & 35 & 35 & $18.41 \pm 0.14$ & 35 & $22.09 \pm 0.28$ \\
\hline S. thrush refrigerated meat $A$ & 35 & 35 & 35 & 35 & 35 & 35 & $16.03 \pm 0.25$ & $19.54 \pm 0.16$ \\
\hline S. thrush refrigerated meat $B$ & 35 & 35 & 35 & 35 & 35 & 35 & $15.81 \pm 0.08$ & $19.40 \pm 0.11$ \\
\hline
\end{tabular}

Average $C_{p}$ value $\pm \mathrm{SD}$ shown from duplicate reactions $C_{p}$ of 35 indicates no amplification. 


\section{TABLE 4}

$\mathrm{C}_{\mathrm{p}}$ values obtained for PCR products amplified with species-specific primers from DNA extracted of commercial meat products containing more than one species in their composition. ( $\mathrm{C}_{\mathrm{p}}$ values produced using $\left.5 \mathrm{ng} \mathrm{DNA}\right)$.

\begin{tabular}{|c|c|c|c|c|c|c|c|c|c|}
\hline Type of product & $\begin{array}{c}\text { Quail } \\
\text { specific PCR } \\
\text { system }\end{array}$ & $\begin{array}{l}\text { Pheasant } \\
\text { specific PCR } \\
\text { system }\end{array}$ & $\begin{array}{l}\text { Partridge } \\
\text { specific PCR } \\
\text { system }\end{array}$ & $\begin{array}{l}\text { Guinea fowl } \\
\text { specific PCR } \\
\text { system }\end{array}$ & $\begin{array}{c}\text { Pigeon } \\
\text { specific PCR } \\
\text { system }\end{array}$ & $\begin{array}{l}\text { Endogenous } \\
\text { control PCR } \\
\text { system }\end{array}$ & $\begin{array}{c}\text { Declared } \\
\text { content of the } \\
\text { target species }\end{array}$ & $\begin{array}{c}\text { Estimated } \\
\text { content of the } \\
\text { target species }\end{array}$ & $\begin{array}{l}\text { Other species detected according to } \\
\text { the label description }\end{array}$ \\
\hline Quail pâté $A$ & $26.56 \pm 0.07$ & 35 & 35 & 35 & 35 & $25.01 \pm 0.07$ & $40 \%$ & $79 \%$ & Cattle, swine, chicken, duck \\
\hline Quail pâté B & $23.37 \pm 0.17$ & 35 & 35 & 35 & 35 & $22.11 \pm 0.07$ & $30 \%$ & $85 \%$ & Cattle, swine, chicken \\
\hline Quail paté C & $25.08 \pm 0.12$ & 35 & 35 & 35 & 35 & $20.77 \pm 0.17$ & $11 \%$ & $8 \%$ & Cattle, swine, chicken, turkey \\
\hline Quail paté C & $21.62 \pm 0.15$ & 35 & 35 & 35 & 35 & $20.23 \pm 0.22$ & $30 \%$ & $71 \%$ & Cattle, swine, chicken \\
\hline Pheasant pâté $A$ & 35 & $19.75 \pm 0.08$ & 35 & 35 & 35 & $18.62 \pm 0.27$ & $20 \%$ & $4 \%$ & Cattle, swine, chicken \\
\hline Pheasant pâté B & 35 & $21.48 \pm 0.03$ & 35 & 35 & 35 & $20.73 \pm 0.18$ & $25 \%$ & $5.5 \%$ & Swine, turkey \\
\hline Pheasant pâté C & 35 & $22.63 \pm 0.08$ & 35 & 35 & 35 & $24.07 \pm 0.11$ & $25 \%$ & $24 \%$ & Cattle, swine, chicken, turkey \\
\hline Pheasant pâté $D$ & 35 & $24.98 \pm 0.23$ & 35 & 35 & 35 & $23.07 \pm 0.11$ & $25 \%$ & $3 \%$ & Cattle, swine, chicken, duck \\
\hline Pheasant pâté E & 35 & $21.45 \pm 0.12$ & 35 & 35 & 35 & $21.06 \pm 0.12$ & $25 \%$ & $7 \%$ & Cattle, swine, chicken, turkey \\
\hline Pheasant pâté $\mathrm{F}$ & 35 & 35 & 35 & 35 & 35 & $23.21 \pm 0.24$ & $32 \%$ & Not detected & Cattle, swine, chicken, turkey \\
\hline Pheasant pâté G & 35 & $28.01 \pm 0.15$ & 35 & 35 & 35 & $22.34 \pm 0.12$ & $2 \%$ & $0.2 \%$ & Cattle, swine, chicken \\
\hline Pheasant pâté H & 35 & $21.66 \pm 0.14$ & 35 & 35 & 35 & $21.35 \pm 0.09$ & $25 \%$ & $8 \%$ & Cattle, swine, chicken, turkey \\
\hline Partridge pâté $A$ & 35 & 35 & 35 & 35 & 35 & $22.05 \pm 0.08$ & $30.5 \%$ & Not detected & Cattle, swine, chicken \\
\hline Partridge paté $B$ & 35 & 35 & $27.24 \pm 0.23$ & 35 & 35 & $21.66 \pm 0.21$ & $30 \%$ & $8 \%$ & Cattle, swine, duck \\
\hline Partridge pâté $C$ & 35 & 35 & $23.55 \pm 0.22$ & 35 & 35 & $19.58 \pm 0.28$ & $-^{a}$ & $17 \%$ & Cattle, swine \\
\hline Partridge pâté $D$ & 35 & 35 & $26.61 \pm 0.09$ & 35 & 35 & $21.32 \pm 0.27$ & - & $9 \%$ & Cattle, swine, chicken, turkey \\
\hline Partridge pâté $\mathrm{E}$ & 35 & 35 & 35 & 35 & 35 & $20.45 \pm 0.24$ & $20 \%$ & Not detected & Cattle, swine, chicken, duck \\
\hline Partridge pâté $F$ & 35 & 35 & 35 & 35 & 35 & $20.68 \pm 0.32$ & $20 \%$ & Not detected & Cattle, swine, chicken, duck \\
\hline Partridge pâté G & 35 & 35 & $24.15 \pm 0.09$ & 35 & 35 & $21.32 \pm 0.07$ & - & $45 \%$ & Cattle, swine, chicken, turkey \\
\hline Partridge pâté H & 35 & 35 & $26.90 \pm 0.12$ & 35 & 35 & $18.05 \pm 0.15$ & - & $0.3 \%$ & Cattle, swine, chicken, duck \\
\hline Partridge pâté I & 35 & 35 & $28.34 \pm 0.23$ & 35 & 35 & $21.55 \pm 0.11$ & - & $3.5 \%$ & Cattle, swine, chicken \\
\hline Partridge pâté J & 35 & 35 & 35 & 35 & 35 & $21.31 \pm 0.22$ & $22 \%$ & Not detected & Cattle, swine, chicken \\
\hline Partridge pâté K & 35 & 35 & 35 & 35 & 35 & $20.45 \pm 0.25$ & $25 \%$ & Not detected & Cattle, swine, chicken, duck \\
\hline
\end{tabular}


TABLE 4 (Continued)

\begin{tabular}{|c|c|c|c|c|c|c|c|c|c|}
\hline Type of product & $\begin{array}{c}\text { Quail } \\
\text { specific PCR } \\
\text { system }\end{array}$ & $\begin{array}{l}\text { Pheasant } \\
\text { specific PCR } \\
\text { system }\end{array}$ & $\begin{array}{l}\text { Partridge } \\
\text { specific PCR } \\
\text { system }\end{array}$ & $\begin{array}{l}\text { Guinea fowl } \\
\text { specific PCR } \\
\text { system }\end{array}$ & $\begin{array}{c}\text { Pigeon } \\
\text { specific PCR } \\
\text { system }\end{array}$ & $\begin{array}{l}\text { Endogenous } \\
\text { control PCR } \\
\text { system }\end{array}$ & $\begin{array}{l}\text { Declared } \\
\text { content of the } \\
\text { target species }\end{array}$ & $\begin{array}{l}\text { Estimated } \\
\text { content of the } \\
\text { target species }\end{array}$ & $\begin{array}{l}\text { Other species detected according to } \\
\text { the label description }\end{array}$ \\
\hline Partridge pâté L & 35 & 35 & $28.62 \pm 0.24$ & 35 & 35 & $21.93 \pm 0.13$ & - & $4 \%$ & Cattle, swine, chicken, turkey \\
\hline Partridge pâté $M$ & 35 & 35 & $24.31 \pm 0.13$ & 35 & 35 & $21.91 \pm 0.31$ & $25 \%$ & $62 \%$ & Cattle, swine, chicken, duck \\
\hline Partridge pâté N & 35 & 35 & 35 & 35 & 35 & $20.11 \pm 0.21$ & $22 \%$ & Not detected & Cattle, swine, chicken \\
\hline Partridge pâté $O$ & 35 & 35 & 35 & 35 & 35 & $21.87 \pm 0.08$ & $30.5 \%$ & Not detected & Cattle, swine, chicken \\
\hline G. fowl pâté $A$ & 35 & 35 & 35 & $24.42 \pm 0.21$ & 35 & $23.14 \pm 0.14$ & $34 \%$ & $1 \%$ & Swine, chicken, turkey \\
\hline G. fowl pâté B & 35 & 35 & 35 & $25.52 \pm 0.08$ & 35 & $25.56 \pm 0.05$ & $20 \%$ & $2.5 \%$ & Swine, duck \\
\hline G. fowl pâté C & 35 & 35 & 35 & $25.12 \pm 0.16$ & 35 & $24.61 \pm 0.05$ & $20 \%$ & $2 \%$ & Cattle, chicken, turkey \\
\hline G. fowl pâté D & 35 & 35 & 35 & $22.62 \pm 0.23$ & 35 & $24.02 \pm 0.21$ & $34 \%$ & $7 \%$ & Swine, chicken, turkey \\
\hline Pigeon pâté $A$ & 35 & 35 & 35 & 35 & $20.27 \pm 0.13$ & $23.51 \pm 0.29$ & $10 \%$ & $26 \%$ & Cattle, swine, chicken, turkey, duck \\
\hline Pigeon pâté $B$ & 35 & 35 & 35 & 35 & $20.45 \pm 0.21$ & $23.08 \pm 0.15$ & $10 \%$ & $17 \%$ & Cattle, swine, chicken, turkey, duck \\
\hline Pigeon pâté C & 35 & 35 & 35 & 35 & $22.97 \pm 0.14$ & $23.20 \pm 0.24$ & - & $3 \%$ & None \\
\hline Pigeon pâté D & 35 & 35 & 35 & 35 & $23.24 \pm 0.16$ & $22.98 \pm 0.12$ & - & $2 \%$ & None \\
\hline
\end{tabular}

Average $C_{p}$ value $\pm S D$ shown from duplicate reactions $C_{p}$ of 35 indicates no amplification. a means not specified content of the target species 